Supporting Information

\title{
A Structurally Characterized Nonheme Cobalt-Hydroperoxo Complex Derived from Its Superoxo Intermediate via Hydrogen Atom Abstraction
}

\begin{abstract}
Chun-Chieh Wang,${ }^{\dagger}$ Hao-Ching Chang, ${ }^{\dagger}$ Yei-Chen Lai, ${ }^{\dagger}$ Huayi Fang, ${ }^{\S}$ Chieh-Chin Li ${ }^{\ddagger}$ Hung-Kai Hsu,${ }^{\dagger}$ Zong-Yan Li,${ }^{\dagger}$ Tien-Sung Lin, ${ }^{\perp}$ Ting-Shen Kuo,${ }^{\dagger}$ Frank Neese, ${ }^{\S}$ Shengfa Ye, ${ }^{*}$, Yun-Wei Chiang, ${ }^{*},{ }^{\ddagger}$ Ming-Li Tsai, ${ }^{*}, \#$ Wen-Feng Liaw, ${ }^{*},+$ and Way-Zen Lee ${ }^{*, \dagger}$
\end{abstract}

†Department of Chemistry and Instrumentation Center, National Taiwan Normal University, Taipei 11677, Taiwan

*Department of Chemistry, National Tsing Hua University, Hsinchu 30013, Taiwan ${ }^{\S}$ Max-Planck Institut für Chemische Energiekonversion, Mülheim an der Ruhr D45470, Germany

${ }^{\perp}$ Department of Chemistry, Washington University, St. Louis, Missouri 63130, United States

\#Department of Chemistry, National Sun Yat-sen University, Kaohsiung 80424, Taiwan 
Materials and Instrumentation. All manipulations were performed under nitrogen using standard Schlenk techniques. Acetonitrile and hexanes were purified by MBraun Solvent Purification System (MB-SPS). Dichloromethane was distilled from $\mathrm{CaH}_{2}$ under nitrogen atmosphere. Tetrahydrofuran (THF), pentane and diethyl ether $\left(\mathrm{Et}_{2} \mathrm{O}\right)$ were dried by distillation from sodium/benzophenone under nitrogen atmosphere. All other chemicals, of analytical or spectroscopic grade, were purchased from commercial sources and used without further purification. 2,6-Bis $(((S)$-2-diphenylhydroxymethyl1-pyrolidinyl)methyl)pyridine $\left(\mathrm{H}_{2} \mathrm{BDPP}\right)^{\mathrm{S} 1}$ and 2,2,6,6-tetramethyl-1-hydroxypiperidine (TEMPOH) were synthesized according to literature procedures. ${ }^{\text {S2 }}$

NMR spectra were recorded on Bruker AV-400 and Bruker AVIII HD-600 NMR spectrometers. UV/Vis spectra were recorded on Agilent 8453 diode-array spectrometer equipped with a cryostat from Unisoku Scientific Instruments, Osaka, Japan. Cyclic voltammetry was performed by a three-electrode technique with a $611 \mathrm{D}$ model, $\mathrm{CH}$ Instruments, Inc. Elemental analyses for $\mathrm{C}, \mathrm{H}$, and $\mathrm{N}$ were performed on an elementar Vario EL cube analyzer at the Instrumentation Center in National Taiwan University. The SQUID measurements were performed on an MPMS-7 magnetometer, Quantum Design, Inc. With 0.5 T external magnetic field, the data were recorded under 2-300 K. Magnetic susceptibility of $\mathbf{1}$ and $\mathbf{2}$ from the experimental data was corrected for diamagnetism by the tabulated Pascal's constants.

Crystals of 1, 2 and $\mathbf{4}$ were selected under a microscope and mounted on the tip of a glass fiber fashioned on a copper pin. X-ray data of 1, 2 and 4 were collected on a Bruker Kappa APEX II CCD diffractometer employing graphite monochromated Mo $\mathrm{K} \alpha$ radiation $(\lambda=0.7107 \AA)$ at $200 \mathrm{~K}$ and a $\theta-2 \theta$ scan mode. The space groups of $\mathbf{1}, \mathbf{2}$ and 4 were determined on the basis of systematic absences and intensity statistics, and the structures of 1, 2 and $\mathbf{4}$ were solved by direct methods using SIR92 or SIR97, and refined using SHELXL-97. An empirical absorption correction by multiscans was applied to the structures of $\mathbf{1}, \mathbf{2}$ and 4. All non-hydrogen atoms were refined with anisotropic displacement factors. H-atoms were placed in ideal positions and fixed with relative isotropic displacement parameters. Detailed crystallographic data of 1, 2 and 4 are provided in CIF files.

\section{Synthesis of Co(BDPP) (1)}

$\mathrm{H}_{2} \mathrm{BDPP}(0.3660 \mathrm{~g}, 0.60 \mathrm{mmol})$ was reacted with $\mathrm{NaH}(0.0432 \mathrm{~g}, 1.80 \mathrm{mmol})$ and $\mathrm{CoCl}_{2}(0.0779 \mathrm{~g}, 0.60 \mathrm{mmol})$ in $\mathrm{THF} / \mathrm{CH}_{3} \mathrm{CN}(1: 1,20 \mathrm{~mL})$ mixed solvent in a $50-\mathrm{mL}$ Schlenk flask. The suspension solution was stirred at room temperature for 12 hours and then vacuumed. The crude was dissolved in $10 \mathrm{ml} \mathrm{CH}_{2} \mathrm{Cl}_{2}$ and filtered; the filtrate was evaporated and re-dissolved using a minimum amount of $\mathrm{CH}_{2} \mathrm{Cl}_{2}$. Addition of $\mathrm{Et}_{2} \mathrm{O}$ $(50 \mathrm{~mL})$ to the concentrated solution resulted purple precipitate of $\mathrm{Co}(\mathrm{BDPP})(\mathbf{1})$. Then, 
$\mathbf{1}$ was isolated and crystallized by slow diffusion of $\mathrm{Et}_{2} \mathrm{O}$ into the $\mathrm{CH}_{2} \mathrm{Cl}_{2}$ solution of $\mathbf{1}$ at room temperature over a day. Purple crystals of 1 were obtained in $65 \%$ yield (0.2914g). UV/Vis $\left(\mathrm{CH}_{2} \mathrm{Cl}_{2}\right): 380 \mathrm{~nm}\left(350 \mathrm{M}^{-1} \cdot \mathrm{cm}^{-1}\right), 600 \mathrm{~nm}\left(35 \mathrm{M}^{-1} \cdot \mathrm{cm}^{-1}\right)$. Anal. Calcd for $\mathrm{C}_{41} \mathrm{H}_{41} \mathrm{CoN}_{3} \mathrm{O}_{2} \cdot \mathrm{CH}_{2} \mathrm{Cl}_{2}$ (F.W. = 751.65): C, 67.11; H, 5.77; N, 5.59. Found: C, 67.481; H, 5.482; N, 5.384 .

\section{Synthesis of $\left[\mathrm{Co}(\mathrm{BDPP})\left(\mathrm{H}_{2} \mathrm{O}\right)\right]\left(\mathrm{BF}_{4}\right)(2)$}

Complex 1 (0.0752 g, $0.10 \mathrm{mmol}))$ was reacted with $\left[\mathrm{Cp}_{2} \mathrm{Fe}\right]\left(\mathrm{BF}_{4}\right)(0.0273 \mathrm{~g}, 0.10$ $\mathrm{mmol}$ ) in $20 \mathrm{~mL}$ of acetone in a 50-mL Schlenk flask. The solution was stirred at room

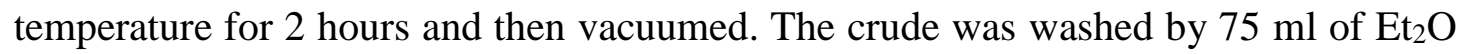
to remove ferrocene, and then dissolved in $10 \mathrm{ml}$ of $\mathrm{CH}_{3} \mathrm{CN}$ and filtered; the filtrate was vacuumed and re-dissolved in a minimum amount of THF. Addition of $\mathrm{Et}_{2} \mathrm{O}$ (50 $\mathrm{mL})$ to the concentrated filtrate resulted reddish precipitate of $\left[\mathrm{Co}(\mathrm{BDPP})\left(\mathrm{H}_{2} \mathrm{O}\right)\right]\left(\mathrm{BF}_{4}\right)$ (2). The isolated residue of 2 was re-dissolved in $\mathrm{THF} / \mathrm{CH}_{3} \mathrm{CN}(5 / 0.1 \mathrm{~mL})$ mixed solvent and crystallized by slow diffusion of $\mathrm{Et}_{2} \mathrm{O}$ into the solution of $\mathbf{2}$ at room temperature for one day. Dark-red crystals of 2 were obtained in $93 \%$ yield $(0.0787 \mathrm{~g})$. UV/Vis $\left(\mathrm{CH}_{3} \mathrm{CN}\right): 380 \mathrm{~nm}\left(160 \mathrm{M}^{-1} \cdot \mathrm{cm}^{-1}\right), 494 \mathrm{~nm}\left(135 \mathrm{M}^{-1} \cdot \mathrm{cm}^{-1}\right)$ and $600 \mathrm{~nm}\left(40 \mathrm{M}^{-1}\right.$ $\cdot \mathrm{cm}^{-1}$ ). Anal. Calcd for $\mathrm{C}_{41} \mathrm{H}_{43} \mathrm{BCoF}_{4} \mathrm{~N}_{3} \mathrm{O}_{3} \cdot \mathrm{C}_{4} \mathrm{H}_{8} \mathrm{O}$ (F.W. = 843.64): C, 64.07; H, 6.09; N, 4.98. Found: C, 63.617; H, 6.048; N, 5.244.

\section{Preparation of $\mathrm{Co}(\mathrm{BDPP})\left(\mathrm{O}_{2}\right)(3)$}

The cobalt(III)-superoxo intermediate, $\mathrm{Co}(\mathrm{BDPP})\left(\mathrm{O}_{2}\right)(3)$, was prepared by bubbling $\mathrm{O}_{2}$ into a THF or $\mathrm{CH}_{2} \mathrm{Cl}_{2}$ solution of $\mathbf{1}$ at $-90{ }^{\circ} \mathrm{C}$ for 30 minutes. The growth of the two absorption bands at 485 and $580 \mathrm{~nm}$ in UV/Vis spectroscopy is the signal for the formation of $\mathbf{3}$.

\section{Synthesis of Co(BDPP)(OOH) (4)}

The navy blue cobalt(III)-hydroperoxo complex, $\mathrm{Co}(\mathrm{BDPP})(\mathrm{OOH})(\mathbf{4})$, was prepared by reacting 3 with two equivalents of TEMPOH at $-90{ }^{\circ} \mathrm{C}$ for 1 hour. Complex 4 was recrystallized by slow diffusion of $\mathrm{Et}_{2} \mathrm{O}$ into the THF solution of 4 at $-20{ }^{\circ} \mathrm{C}$. Dark blue crystals of 4 were obtained over a week. UV/vis (THF): $375 \mathrm{~nm}, 585 \mathrm{~nm}$ and $660 \mathrm{~nm}$. 


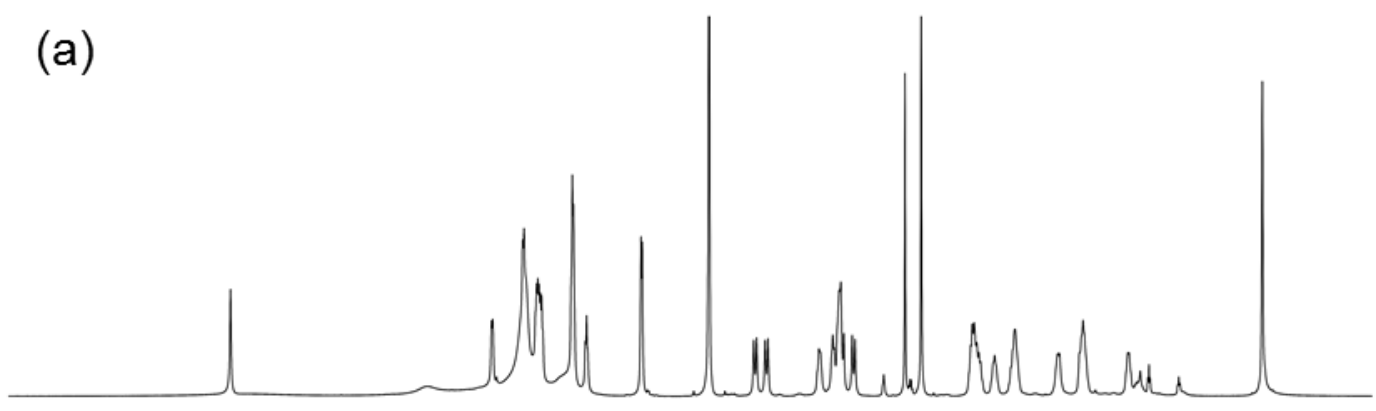

(b)

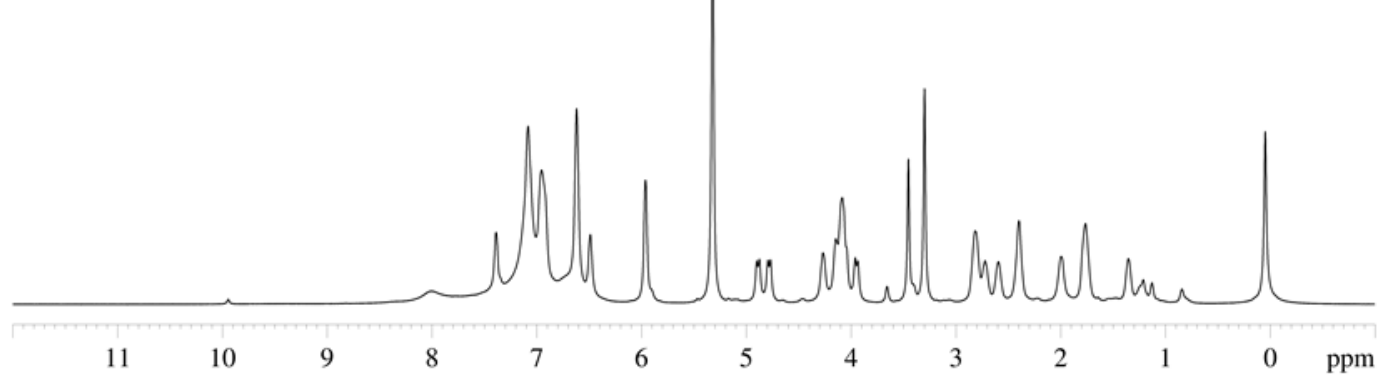

Figure S1. (a) ${ }^{1} \mathrm{H}$ NMR spectrum of $\mathrm{Co}(\mathrm{BDPP})(\mathrm{OOH})(4)$ (b) ${ }^{1} \mathrm{H}$ NMR spectrum of 4 adding few drops of $\mathrm{D}_{2} \mathrm{O}$. The signal for the proton of the $\mathrm{OOH}^{-}$group at $9.88 \mathrm{ppm}$ disappears upon addition of $\mathrm{D}_{2} \mathrm{O}$. Above spectra were recorded in $\mathrm{CD}_{2} \mathrm{Cl}_{2}$ at $-20{ }^{\circ} \mathrm{C}$. 


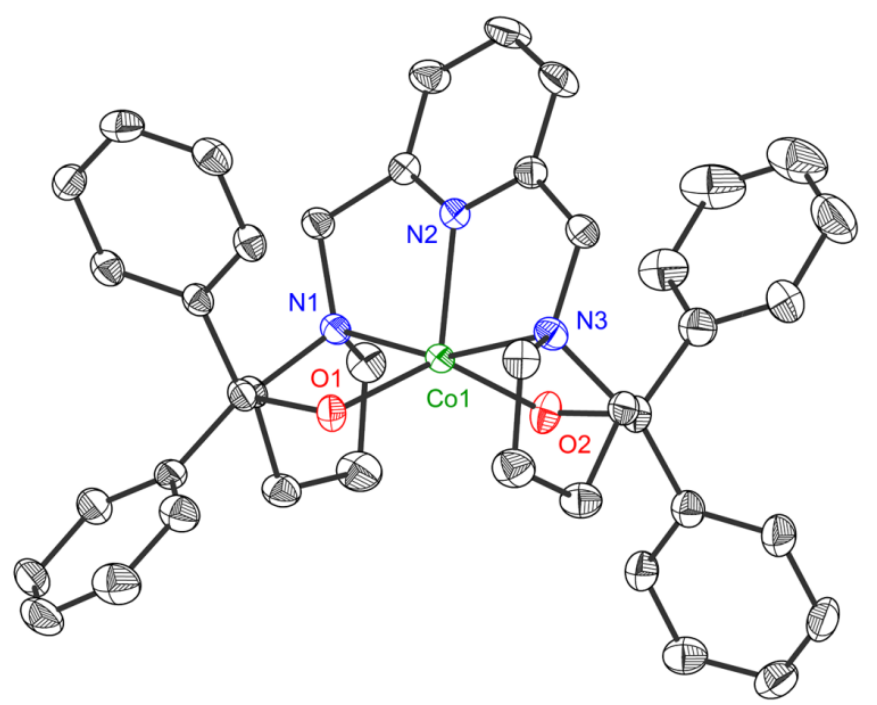

Complex 1 (hydrogen atoms are omitted for clarity) 
Table S1. Crystal data and structure refinement for Co(BDPP) (1).

Empirical formula

Formula weight

Temperature

Wavelength

Crystal system

Space group

Unit cell dimensions

Volume

$\mathrm{Z}$

Density (calculated)

Absorption coefficient

$\mathrm{F}(000)$

Crystal size

Theta range for data collection

Index ranges

Reflections collected

Independent reflections

Completeness to theta $=25.04^{\circ}$

Absorption correction

Max. and min. transmission

Refinement method

Data / restraints / parameters

Goodness-of-fit on $\mathrm{F}^{2}$

Final R indices [I $>2 \operatorname{sigma}(\mathrm{I})]$

$\mathrm{R}$ indices (all data)

Absolute structure parameter

Largest diff. peak and hole
$\mathrm{C} 42 \mathrm{H} 43 \mathrm{Cl} 2 \mathrm{Co} \mathrm{N} 3 \mathrm{O} 2$

751.62

200(2) K

$0.71073 \AA$

Orthorhombic

P $2{ }_{1} 22_{1}$

$a=20.9019(19) \AA \quad \alpha=90^{\circ}$

$\mathrm{b}=8.6240(7) \AA \quad \beta=90^{\circ}$

$\mathrm{c}=10.1737(9) \AA \quad \gamma=90^{\circ}$

1833.9(3) $\AA^{3}$

2

$1.361 \mathrm{Mg} / \mathrm{m}^{3}$

$0.654 \mathrm{~mm}^{-1}$

786

$0.31 \times 0.25 \times 0.07 \mathrm{~mm}^{3}$

1.95 to $25.04^{\circ}$

$-24 \leq \mathrm{h} \leq 17,-9 \leq \mathrm{k} \leq 10,-6 \leq 1 \leq 11$

6792

$3007[\mathrm{R}($ int $)=0.0392]$

$96.8 \%$

multi-scan

0.9556 and 0.8229

Full-matrix least-squares on $\mathrm{F}^{2}$

3007 / 0 / 241

1.027

$\mathrm{R}_{1}=0.0512, \mathrm{wR}_{2}=0.0993$

$\mathrm{R}_{1}=0.0681, \mathrm{wR}_{2}=0.1082$

$0.05(3)$

0.421 and $-0.355 \mathrm{e} \cdot \AA^{-3}$ 


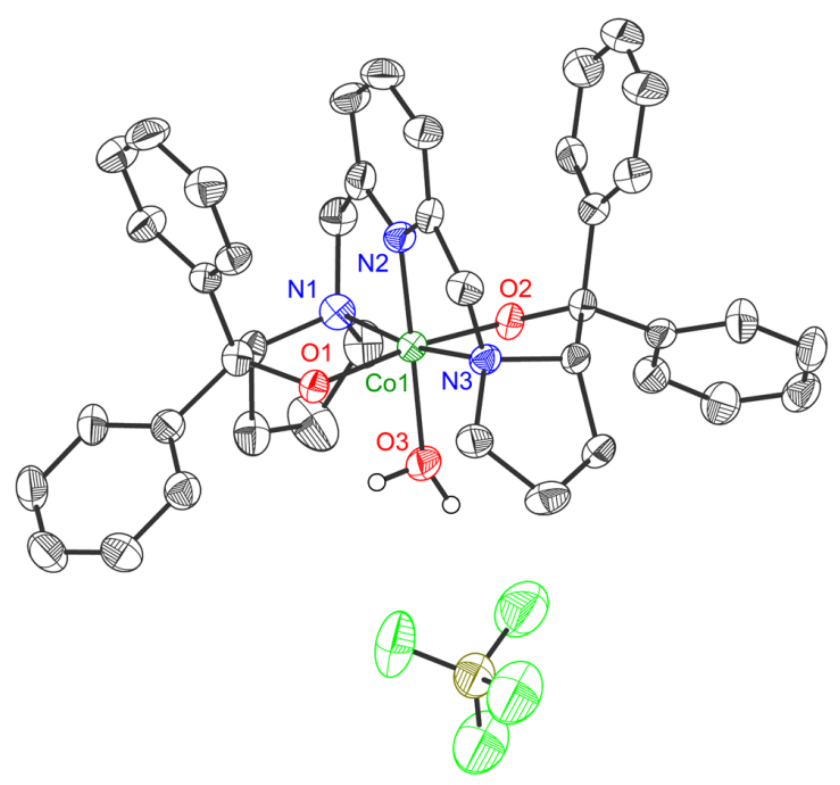

Complex 2 (hydrogen atoms except aqua hydrogens are omitted for clarity) 
Table S2. Crystal data and structure refinement for $\left[\mathrm{Co}(\mathrm{BDPP})\left(\mathrm{H}_{2} \mathrm{O}\right)\right]\left(\mathrm{BF}_{4}\right)(2)$.

Empirical formula

Formula weight

Temperature

Wavelength

Crystal system

Space group

Unit cell dimensions

Volume

$\mathrm{Z}$

Density (calculated)

Absorption coefficient

$\mathrm{F}(000)$

Crystal size

Theta range for data collection

Index ranges

Reflections collected

Independent reflections

Completeness to theta $=25.08^{\circ}$

Absorption correction

Max. and min. transmission

Refinement method

Data / restraints / parameters

Goodness-of-fit on $\mathrm{F}^{2}$

Final R indices [I $>2 \operatorname{sigma}(\mathrm{I})]$

$\mathrm{R}$ indices (all data)

Absolute structure parameter

Largest diff. peak and hole
C45 H51 B Co F4 N3 O4

843.63

200(2) K

$0.71073 \AA$

Orthorhombic

P $2{ }_{1} 22_{1}$

$\mathrm{a}=13.6583(12) \AA$

$\alpha=90^{\circ}$

$\mathrm{b}=13.9494(13) \AA$

$\beta=90^{\circ}$

$\mathrm{c}=20.9920(16) \AA$

$\gamma=90^{\circ}$

3999.5(6) $\AA^{3}$

4

$1.401 \mathrm{Mg} / \mathrm{m}^{3}$

$0.496 \mathrm{~mm}^{-1}$

1768

$0.78 \times 0.37 \times 0.31 \mathrm{~mm}^{3}$

1.75 to $25.08^{\circ}$

$-16 \leq \mathrm{h} \leq 13,-16 \leq \mathrm{k} \leq 16,-24 \leq 1 \leq 15$

26645

$7109[\mathrm{R}($ int $)=0.0509]$

$100.0 \%$

None

0.8614 and 0.6982

Full-matrix least-squares on $\mathrm{F}^{2}$

7109 / 2 / 497

1.103

$\mathrm{R}_{1}=0.0578, \mathrm{wR}_{2}=0.1596$

$\mathrm{R}_{1}=0.0771, \mathrm{wR}_{2}=0.1855$

$-0.02(2)$

1.226 and $-0.823 \mathrm{e} \cdot \AA^{-3}$ 


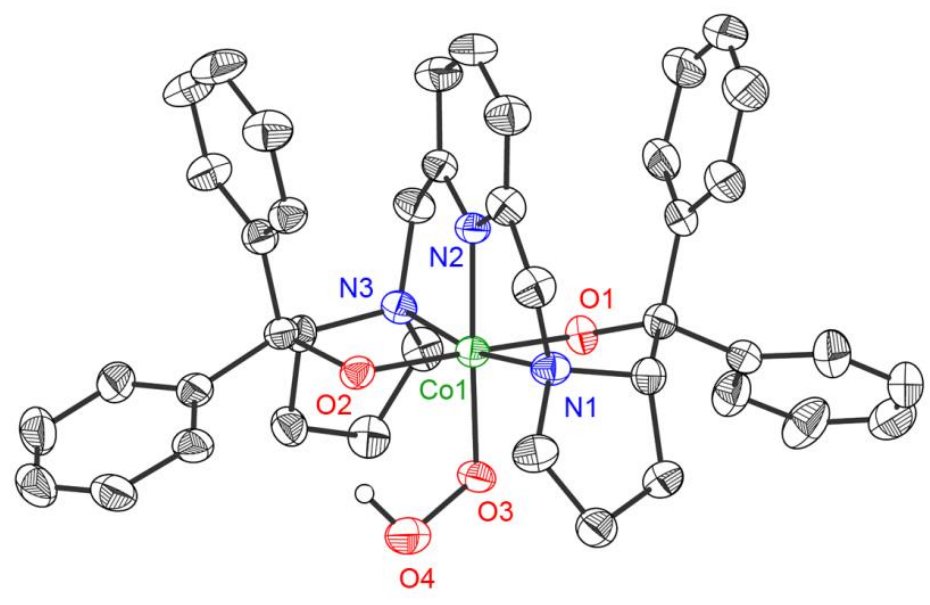

Complex 4 (hydrogen atoms except hydroperoxo hydrogen are omitted for clarity) 
Table S3. Crystal data and structure refinement for $\mathrm{Co}(\mathrm{BDPP})(\mathrm{OOH})(\mathbf{4})$.

Identification code

Empirical formula

Formula weight

Temperature

Wavelength

Crystal system

Space group

Unit cell dimensions

Volume

$\mathrm{Z}$

Density (calculated)

Absorption coefficient

$\mathrm{F}(000)$

Crystal size

Theta range for data collection

Index ranges

Reflections collected

Independent reflections

Completeness to theta $=25.13^{\circ}$

Absorption correction

Max. and min. transmission

Refinement method

Data / restraints / parameters

Goodness-of-fit on $\mathrm{F}^{2}$

Final R indices [I $>2 \operatorname{sigma}(\mathrm{I})]$

$\mathrm{R}$ indices (all data)

Absolute structure parameter

Largest diff. peak and hole $\operatorname{ch} 18152$

C45 H54 Co N3 O7

807.84

200(2) K

$0.71073 \AA$

Orthorhombic

P $2{ }_{1} 22_{1}$

$\mathrm{a}=13.5048(14) \AA \quad \alpha=90^{\circ}$

$\mathrm{b}=13.8737(15) \AA \quad \beta=90^{\circ}$

$\mathrm{c}=21.217(3) \AA \quad \gamma=90^{\circ}$

3975.2(8) $\AA^{3}$

4

$1.350 \mathrm{Mg} / \mathrm{m}^{3}$

$0.488 \mathrm{~mm}^{-1}$

1712

$0.78 \times 0.39 \times 0.18 \mathrm{~mm}^{3}$

2.42 to $25.13^{\circ}$.

$-13 \leq \mathrm{h} \leq 16,-16 \leq \mathrm{k} \leq 16,-25 \leq 1 \leq 25$

26959

7017 [R(int) $=0.0339]$

$99.7 \%$

multi-scan

0.9173 and 0.7022

Full-matrix least-squares on $\mathrm{F}^{2}$

7017 / 0 / 499

1.035

$\mathrm{R}_{1}=0.0381, \mathrm{wR}_{2}=0.0979$

$\mathrm{R}_{1}=0.0437, \mathrm{wR}_{2}=0.1015$

$0.005(13)$

0.666 and $-0.657 \mathrm{e} \cdot \AA^{-3}$ 


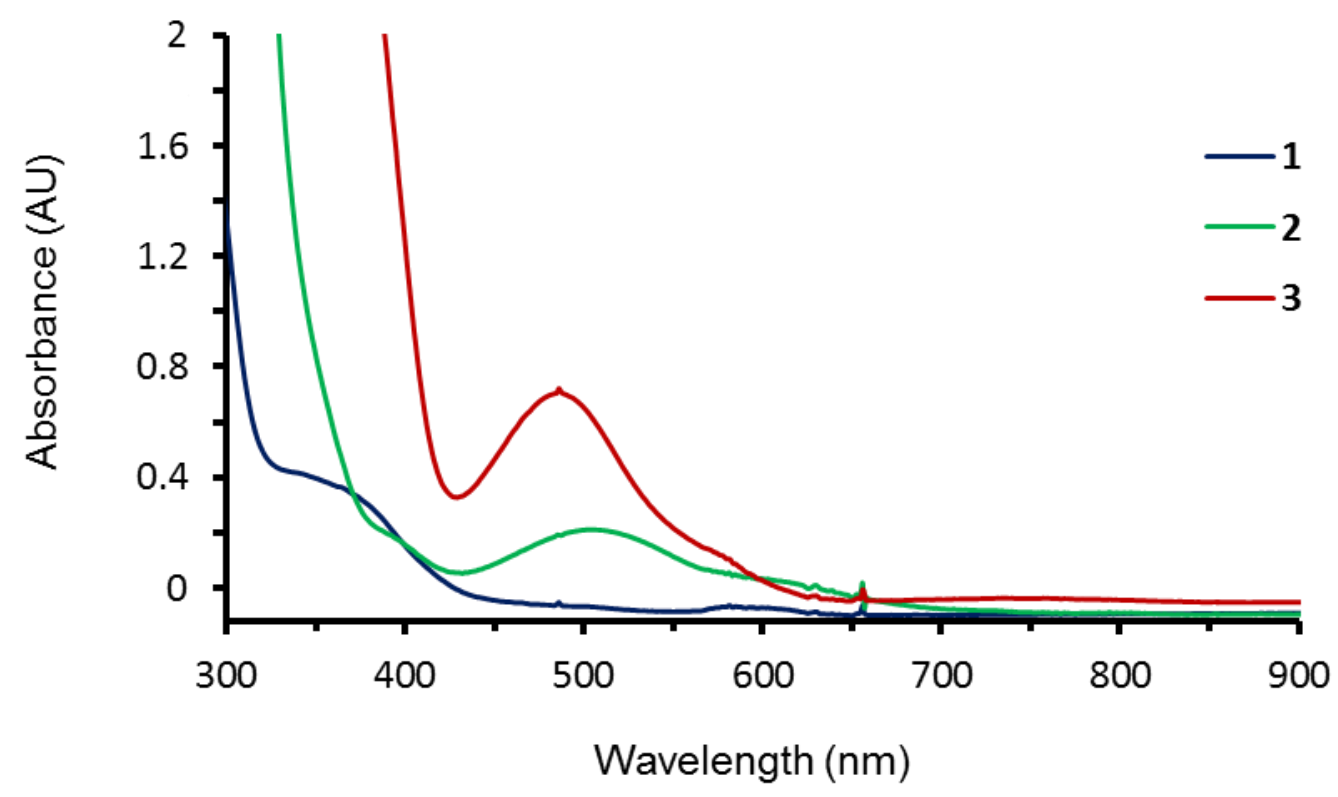

Figure S2. UV/Vis spectra of $\mathbf{1}$ (blue, $1 \mathrm{mM}$ ), 2 (green, $1 \mathrm{mM}$ ) and $\mathbf{3}$ (red, $1 \mathrm{mM}$ ), measured in THF at $-90{ }^{\circ} \mathrm{C}$.

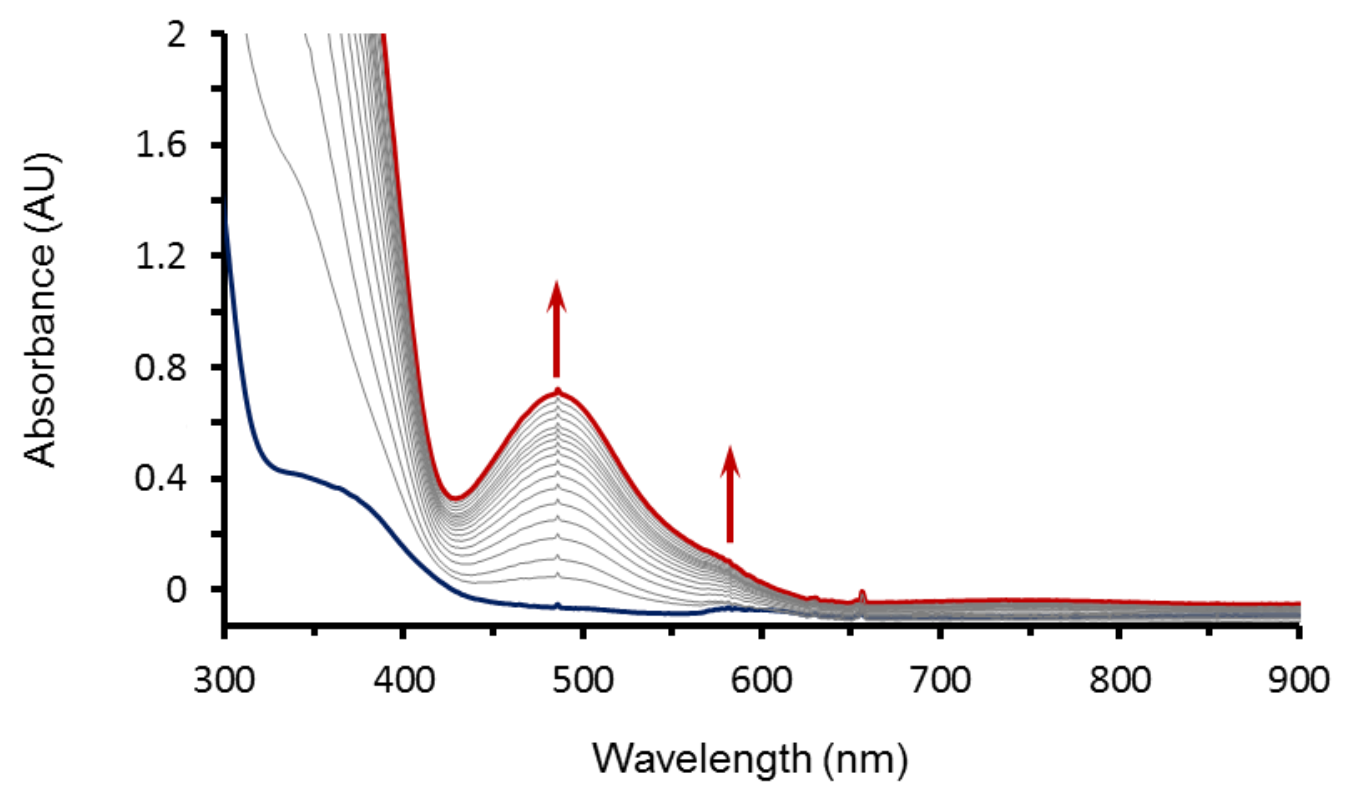

Figure S3. Conversion of 1 (blue, $1 \mathrm{mM}$ ) to $\mathbf{3}$ (red) by bubbling $\mathrm{O}_{2}$ into the THF solution of 1 under $-90^{\circ} \mathrm{C}$. Two absorption bands grow at 485 and $580 \mathrm{~nm}$. 


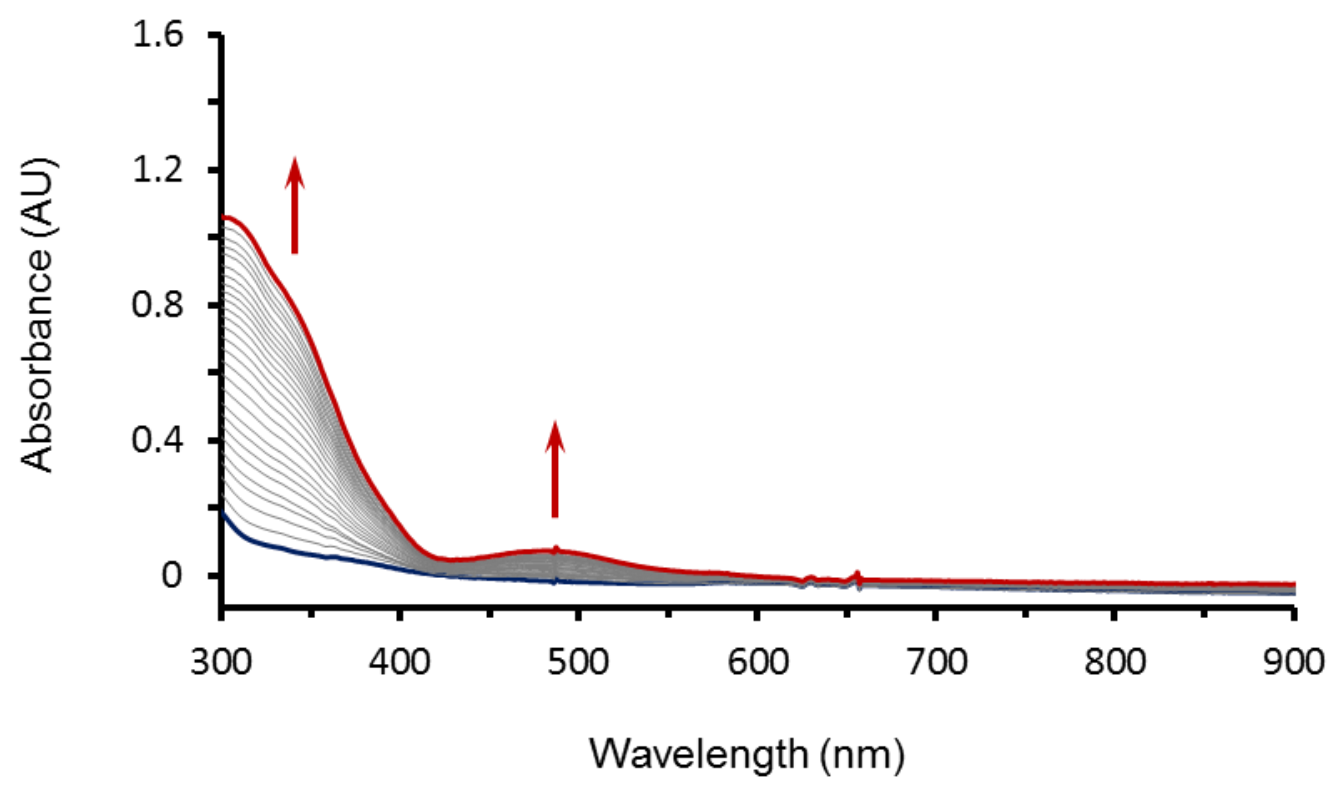

Figure S4. Conversion of 1 (blue, $0.1 \mathrm{mM}$ ) to 3 (red) by bubbling $\mathrm{O}_{2}$ into the THF solution of 1 under $-90^{\circ} \mathrm{C}$. Two absorption bands grow at 340 and $485 \mathrm{~nm}$.

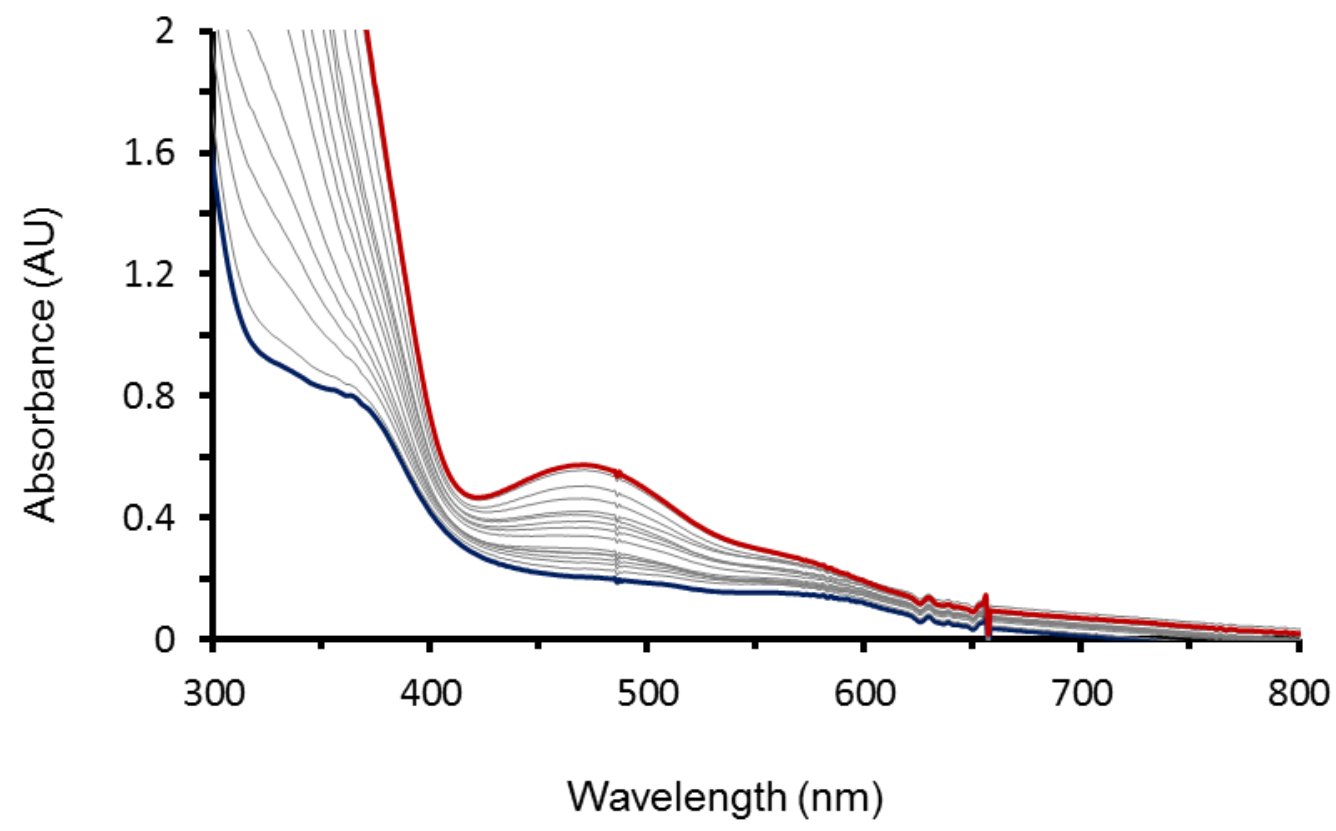

Figure S5. Conversion of $\mathbf{1}$ (blue, $1 \mathrm{mM}$ ) to $\mathbf{3}$ (red) by bubbling $\mathrm{O}_{2}$ into the $\mathrm{CH}_{2} \mathrm{Cl}_{2}$ solution of 1 under $-90{ }^{\circ} \mathrm{C}$. 


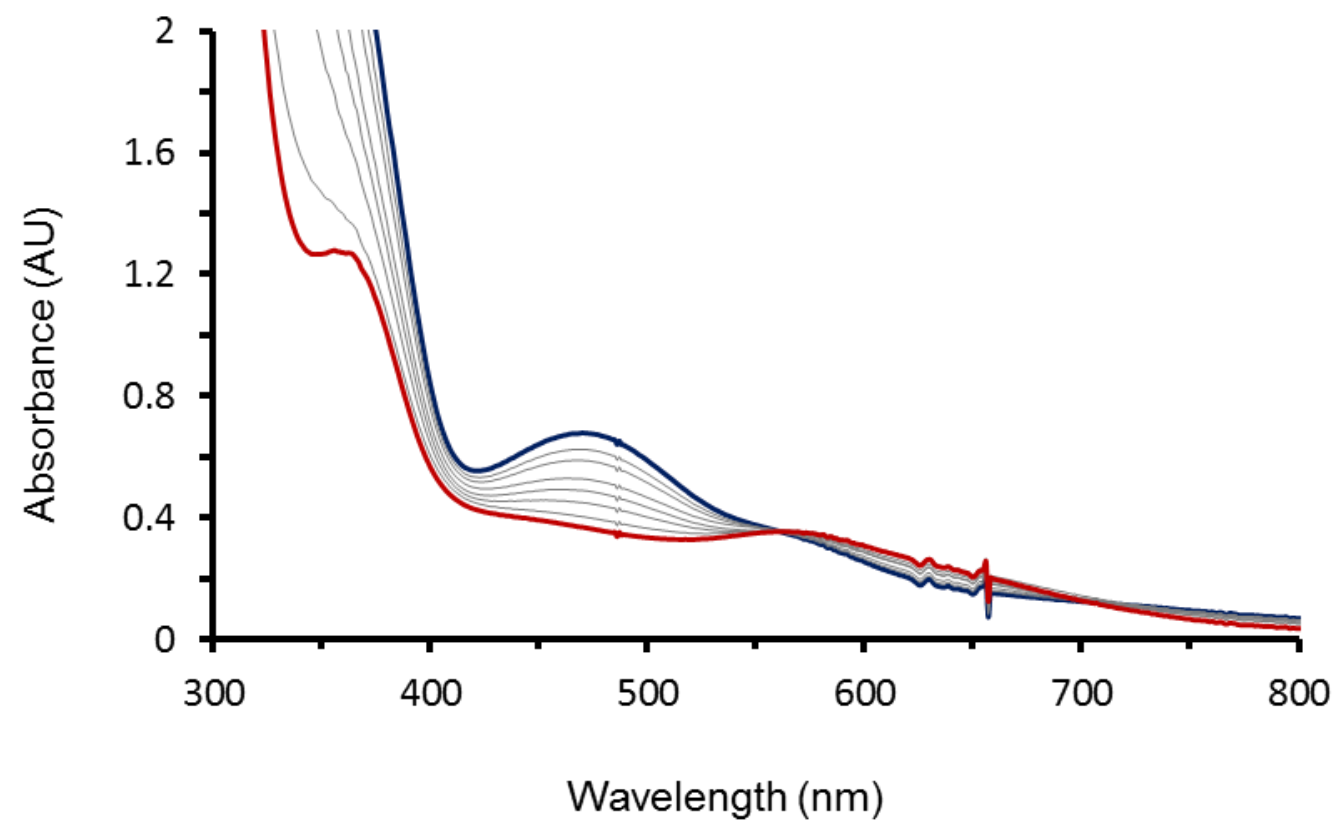

Figure S6. Conversion of 3 (blue, $1 \mathrm{mM}$ ) to 4 (red) by reacting 3 with 2 equivalents of TEMPOH in $\mathrm{CH}_{2} \mathrm{Cl}_{2}$ under $-90{ }^{\circ} \mathrm{C}$.

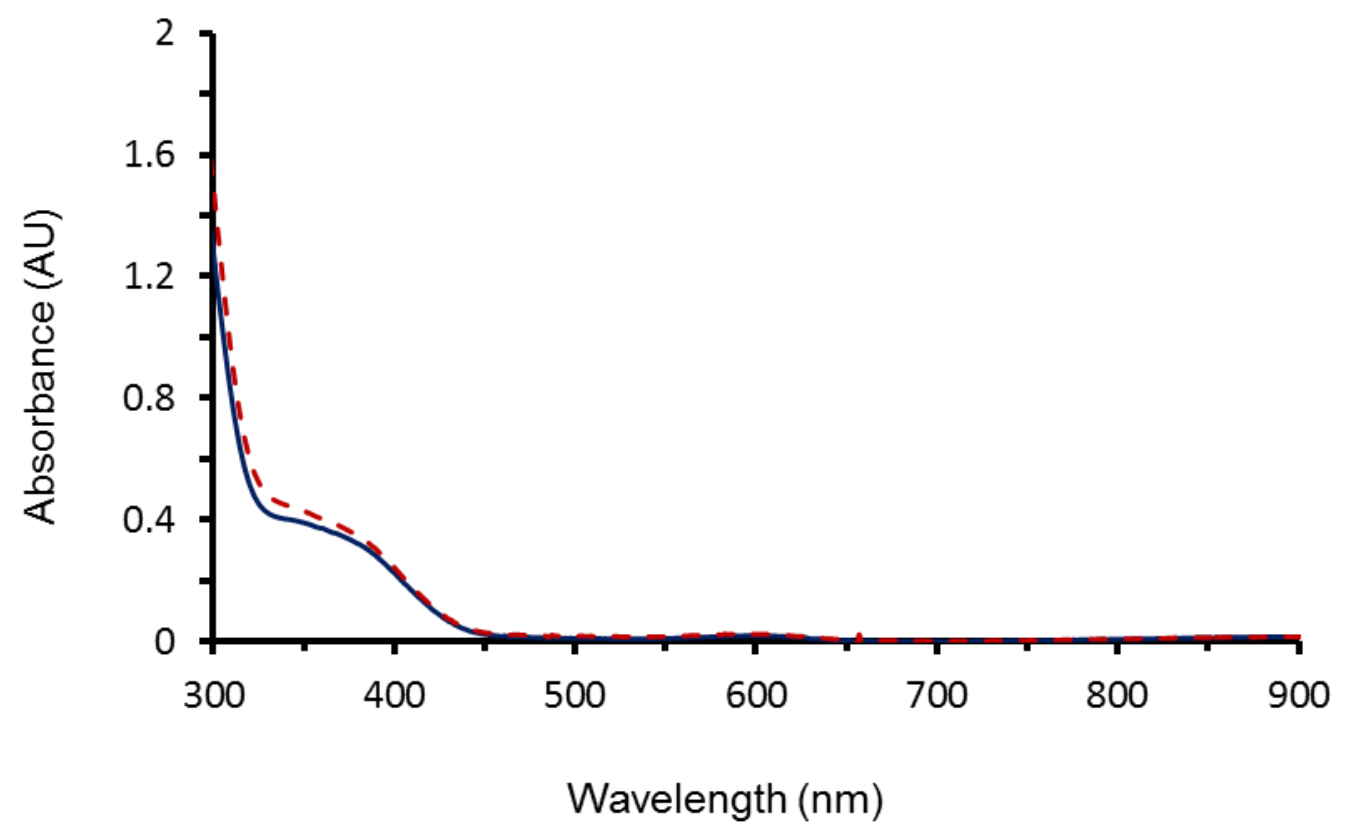

Figure S7. UV/Vis Monitoring for the reaction of 1 with $\mathrm{O}_{2}$ in THF at room temperature. The blue line is the spectrum of $\mathbf{1}$, and the red dash line is the resulting spectrum after $\mathrm{O}_{2}$ bubbling for 2 hours. Formation of cobalt-superoxo 3 is not observed. 


\section{Complex 4 prepared from the reaction of 2 with excess $\mathrm{H}_{2} \mathrm{O}_{2}$ and $\mathrm{NEt}_{3}$}

At room temperature, complex 2 (0.0034 g) dissolved in $4 \mathrm{~mL} \mathrm{THF} / \mathrm{CH}_{3} \mathrm{CN}(7: 1)$ mixed solvent was treated with excess $\mathrm{H}_{2} \mathrm{O}_{2}$ but it didn't reveal obvious changes on UV-vis spectrum. After adding excess $\mathrm{NEt}_{3}$ into the solution for 15 minutes, the color of reaction solution changed to navy blue (Figure S8). This spectrum shares the similar d$\mathrm{d}$ transitions of $\mathrm{Co}(\mathrm{BDPP})(\mathrm{OOH})(4)$, prepared from 3 with TEMPOH at $-90{ }^{\circ} \mathrm{C}$. The difference within ultraviolet region is attributed to the distinct temperatures affecting those charged-transfer bands between the two preparative ways.

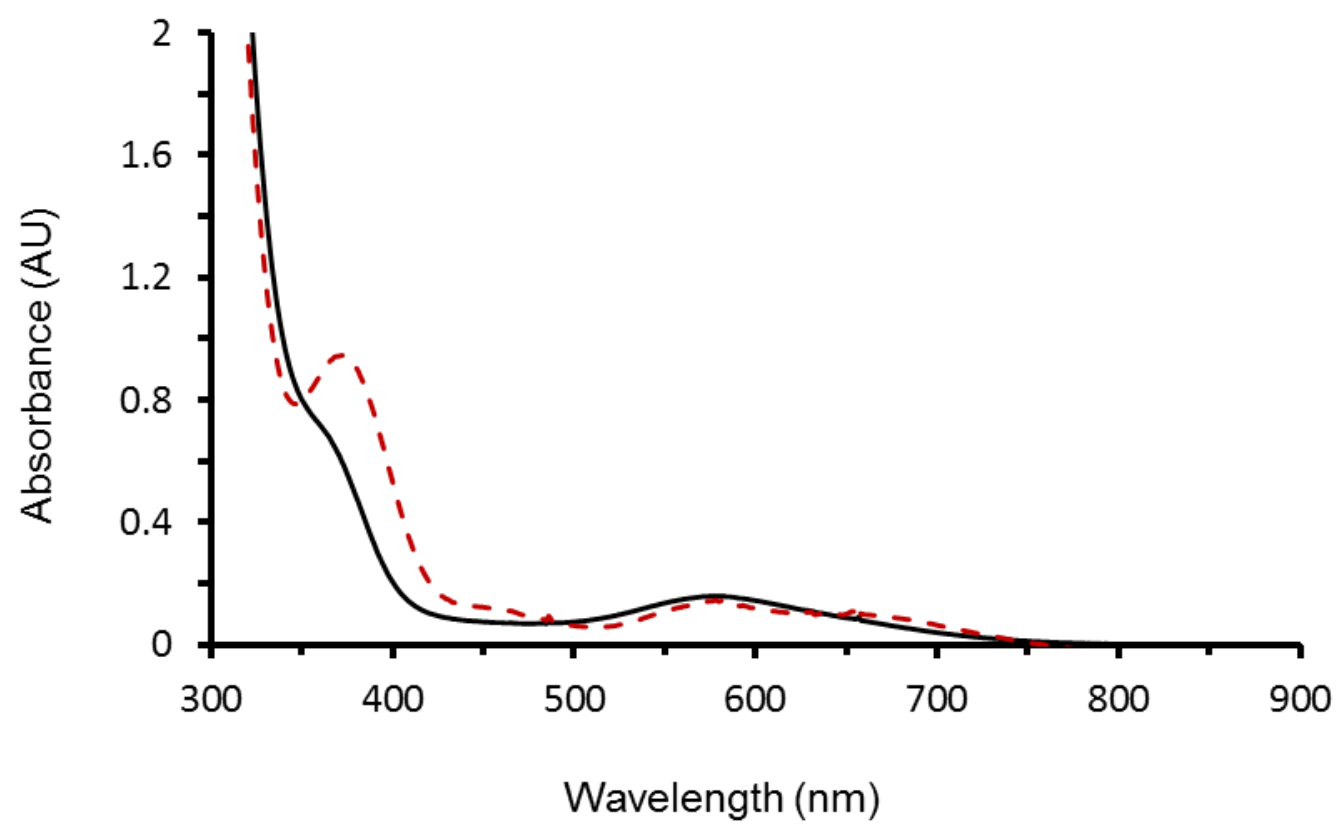

Figure S8. UV/Vis spectra of $\mathbf{4}$ from synthetic routes. The black line is the spectrum of 4 prepared from the reaction of 2 with excess $\mathrm{H}_{2} \mathrm{O}_{2}$ and $\mathrm{NEt}_{3}$ at $25{ }^{\circ} \mathrm{C}$; the red dash line is the one from the reaction of $\mathbf{3}$ with TEMPOH at $-90{ }^{\circ} \mathrm{C}$. 


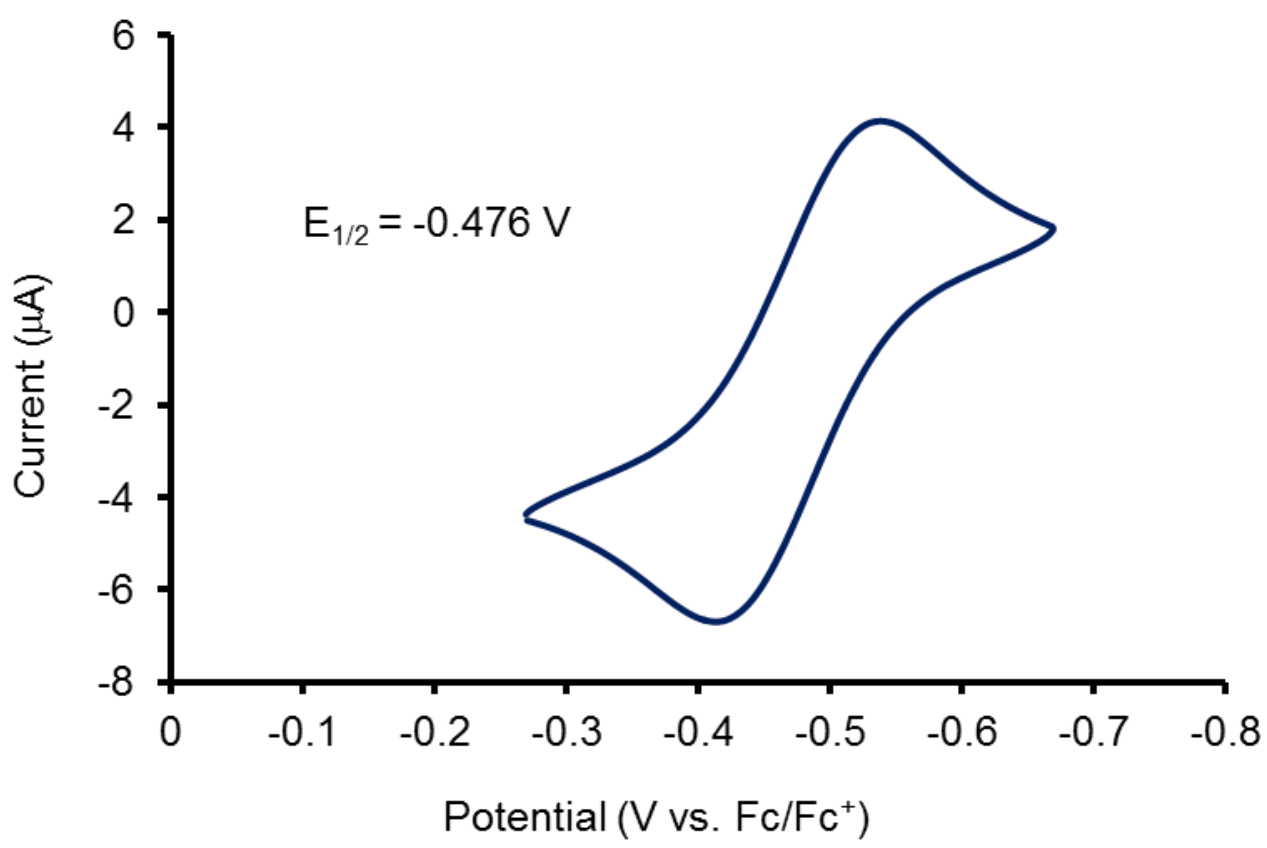

Figure S9. Cyclic voltammetry of 1 in $\mathrm{CH}_{2} \mathrm{Cl}_{2}$ with $0.1 \mathrm{M}\left(\mathrm{N}^{n} \mathrm{Bu}_{4}\right)\left(\mathrm{BF}_{4}\right)$ as supporting electrolyte. Glassy carbon and Pt were utilized as working and counter electrodes, while a silver wire was used as a reference electrode. The potential is calibrated by the ferrocenium/ferrocene redox couple.

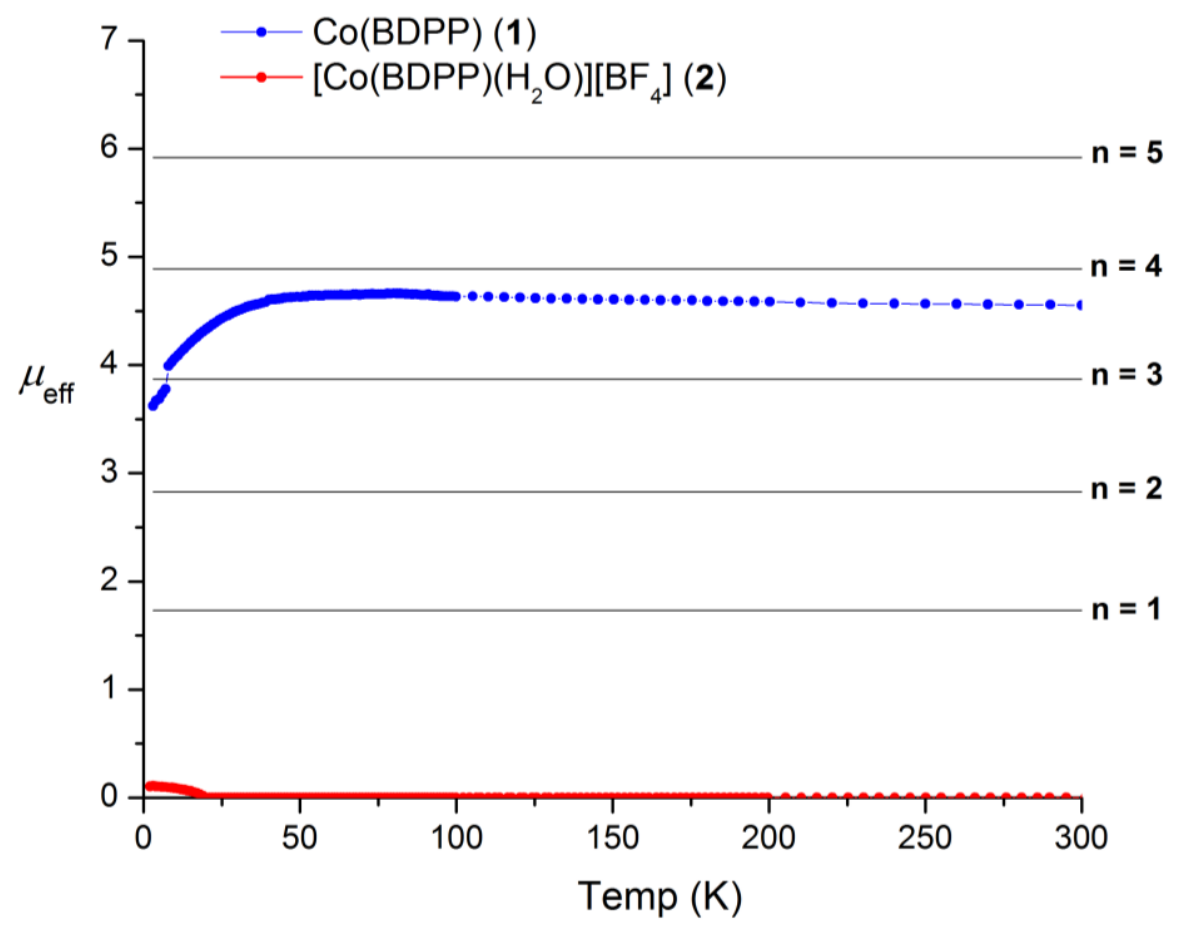

Figure S10. The plot of effective magnetic moments ( $\left.\mu_{\mathrm{eff}}\right)$ vs. temperature for $\mathbf{1}$ (blue) and 2 (red). 


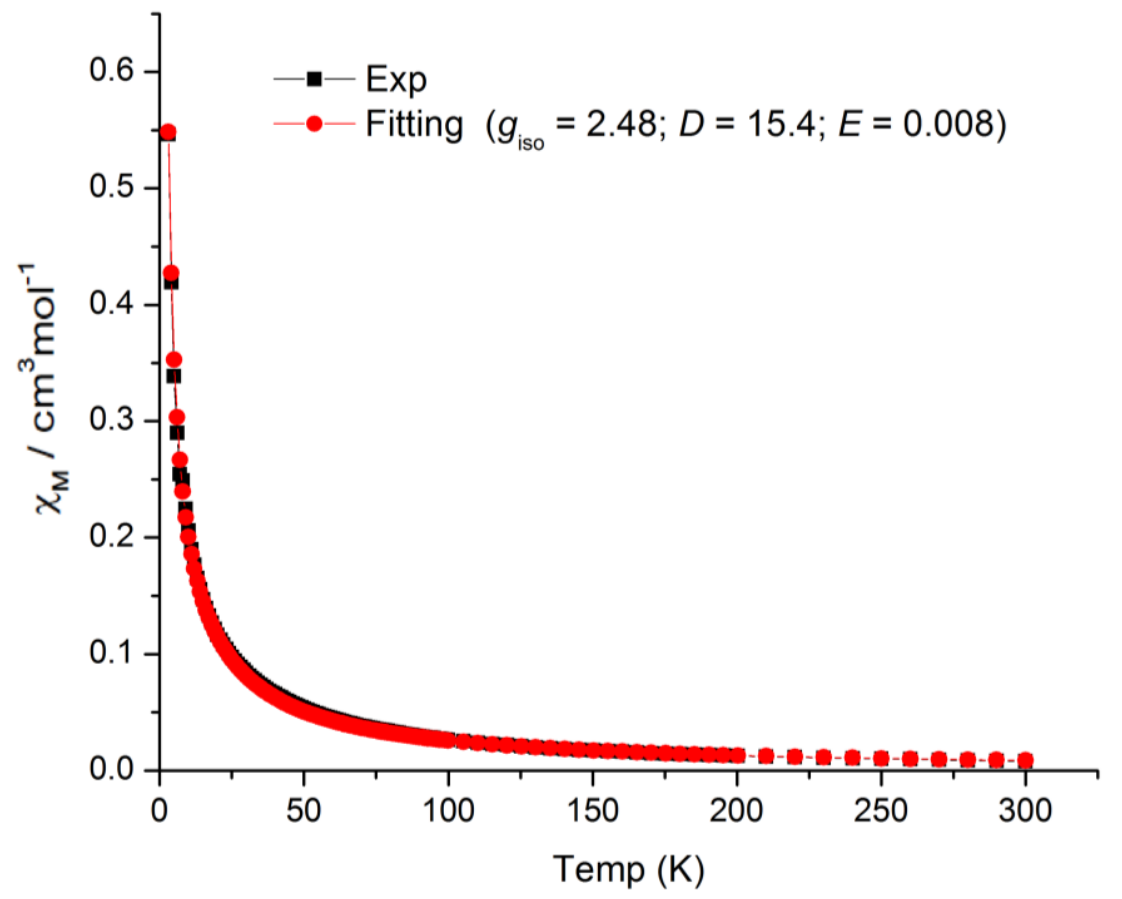

Figure S11. The plot of magnetic susceptibility of $\mathbf{1}$. The best fit (red spots) to the magnetic susceptibility curve $(2-300 \mathrm{~K})$ gives $|D|=15.4 \mathrm{~cm}^{-1},|E|=0.008 \mathrm{~cm}^{-1}$, and $g_{\text {iso }}$ $=2.48$ (the values of $D$ and $E$ are shown by their absolute values because the sign cannot be unambiguously determined by fitting of the powder susceptibility data). These data were fitted by ANISOFIT program ${ }^{\mathrm{S} 3}$ (considering ground state population only) including axial zero-field splitting $(D)$, rhombicity of the system $(E)$, and Zeeman interactions and incorporate a full powder average. 


\section{CW/Pulsed EPR Measurements and Data Analysis}

A Bruker ELEXSYS E580 cw/pulse spectrometer, equipped with a split ring resonator (ER4118X-MS3), and a helium gas flow system (4118CF and 4112HV), was used. A $40 \mu \mathrm{L}$ aliquot of the sample was transferred into an EPR quartz tube with an inner diameter of $3 \mathrm{~mm}$. All samples were frozen quickly by immersion in liquid nitrogen. Then the samples were inserted into the EPR cavity which was precooled to the desired temperature. CW-EPR experiments were performed at 4 or $77 \mathrm{~K}$ with a microwave frequency of approximately $9.52 \mathrm{GHz}$. The magnetic field was swept from 0 to $6000 \mathrm{G}$ for 8196 data points, with a modulation frequency of $100 \mathrm{kHz}$, and a microwave power of $1.5 \mathrm{~mW}$. Spectral analysis and simulations were performed using the EasySpin program.

Three-pulse electron spin echo envelope modulation (ESEEM) experiments were performed at $30 \mathrm{~K}$, using a $\pi / 2-\tau-\pi / 2-\mathrm{T}-\pi / 2-\tau$ stimulated echo with a pulse length $\pi / 2$ (16 ns), $\tau$ value of $136 \mathrm{~ns}$, T values starting from $300 \mathrm{~ns}$ with a time increment $\Delta \mathrm{T}$ of 4 $\mathrm{ns}$, and magnetic field strength fixed at $3352 \mathrm{G}$. A $\tau$ variation experiment was performed to confirm the $\tau$ value of $136 \mathrm{~ns}$ avoids the blind spot condition. Four-step phase cycling was employed to eliminate unwanted echoes. The raw data were phase corrected, and the real part was selected. After the baseline correction, the final spectra were obtained as the magnitude of the Fourier transformed signals. Theoretical analysis of the threepulse ESEEM data was performed using the OPTESIM program. ${ }^{\mathrm{S} 4}$

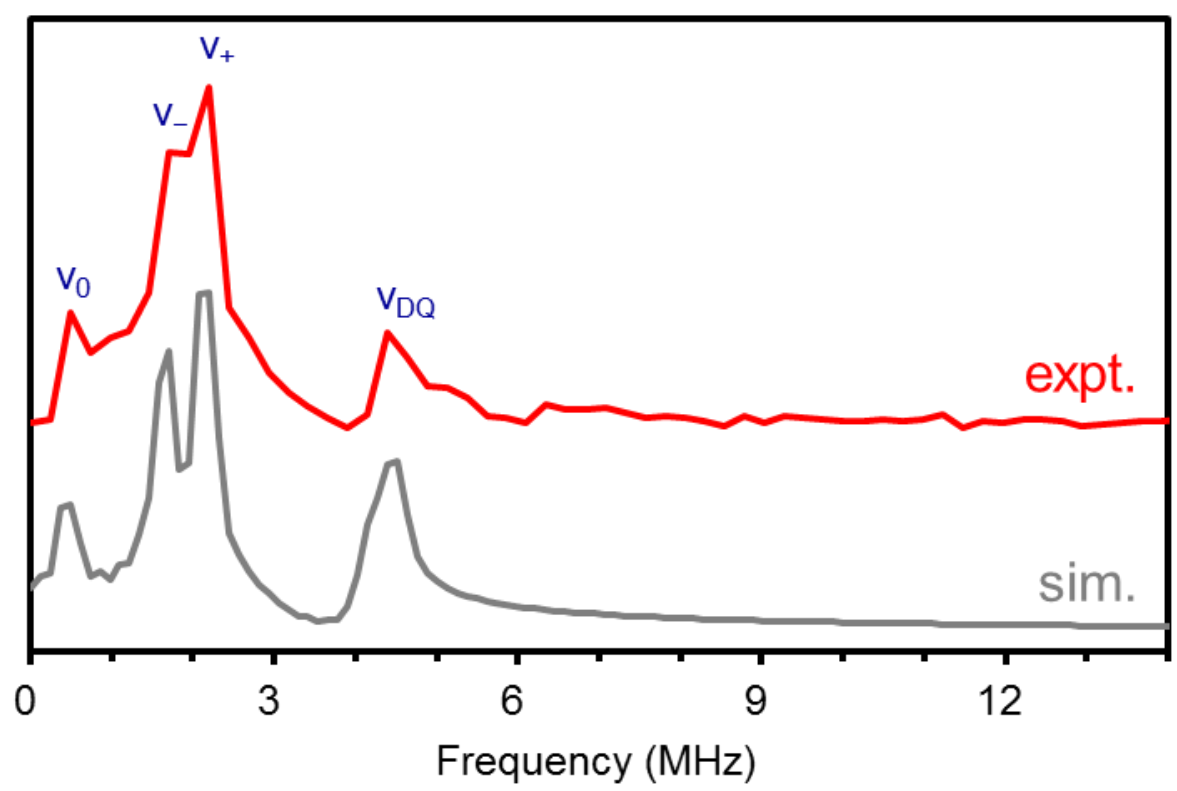

Figure S12. Experimental (red) and simulated (gray) three-pulse ESEEM spectra of 3. 


\section{Reactivity of 3 with TEMPOH (EPR analysis)}

Calibration curve (Figure S10) of TEMPO' was made, from $0.5 \mathrm{mM}$ to $2 \mathrm{mM}$ in $0.5 \mathrm{ml}$ aliquots, by EPR measurements at $77 \mathrm{~K}$. data. The double integration of TEMPO` signal at $g=2.006$ is reproducible and has good linearity in the concentration range.

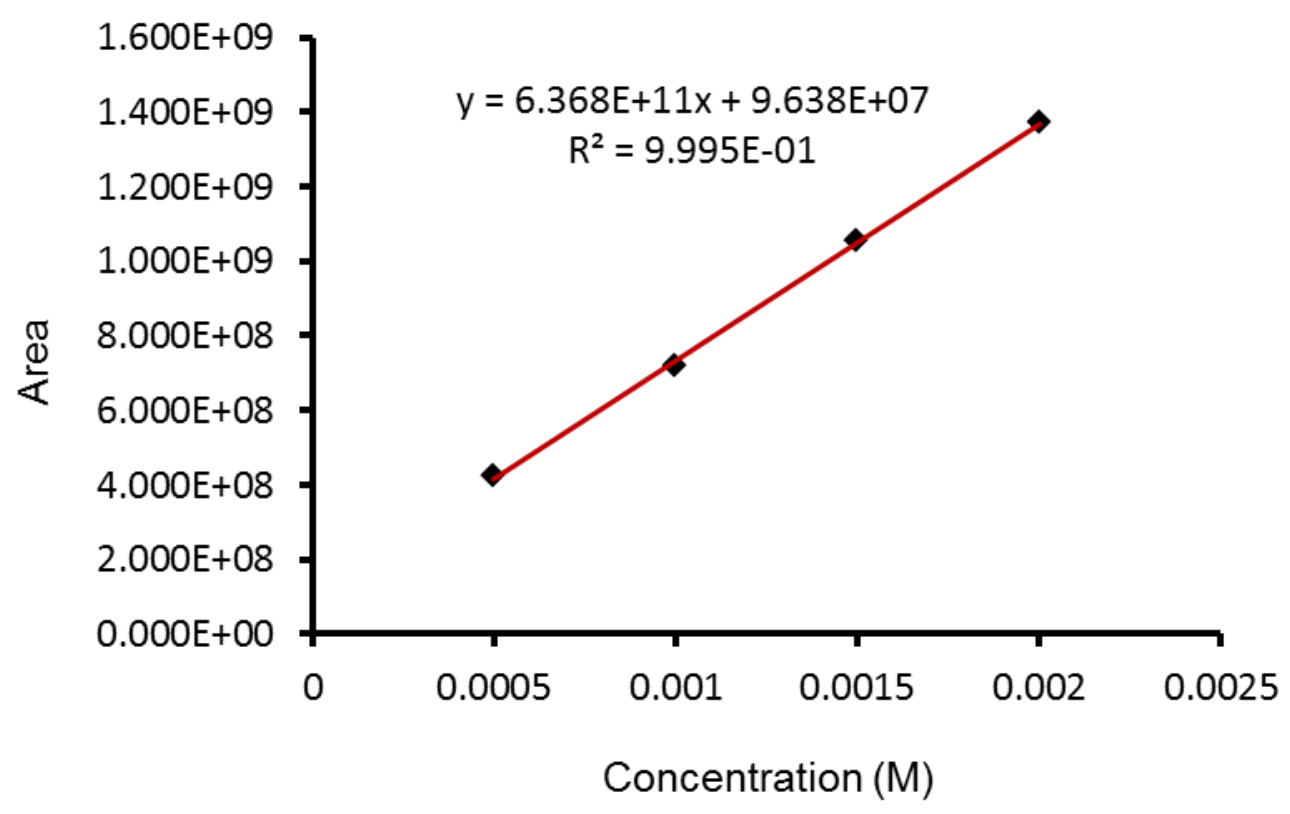

Figure S13. Calibration curve of TEMPO:

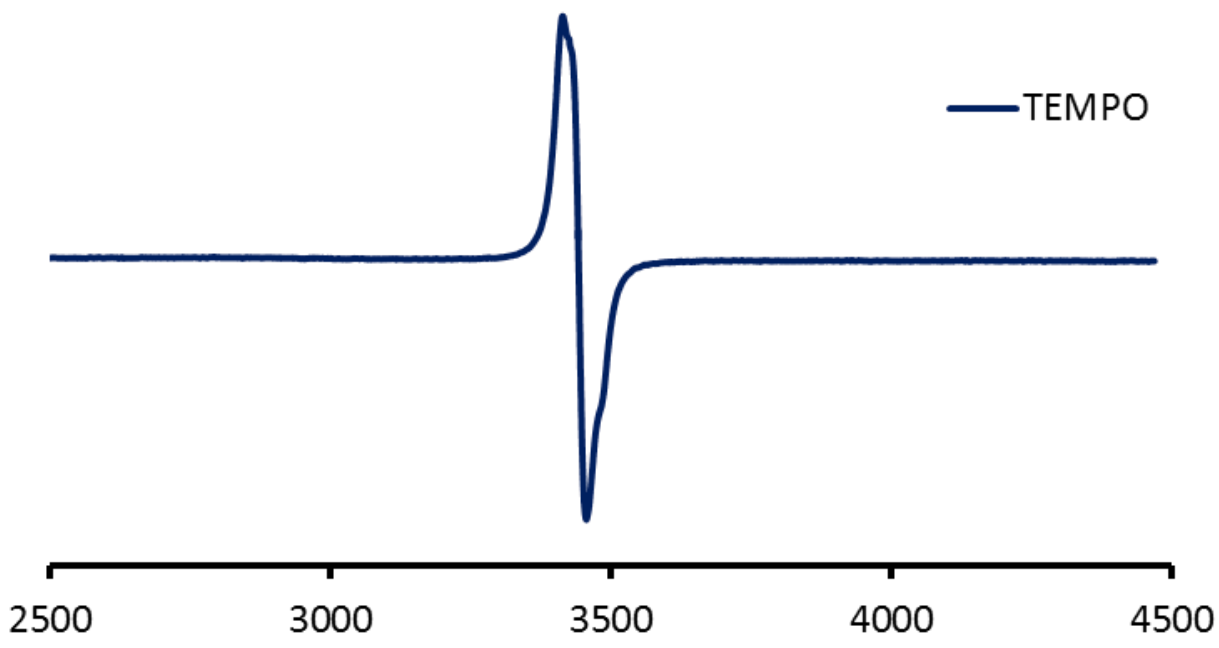

Magnetic field (G)

Figure S14. 77 K EPR spectrum of TEMPO` derived from the reaction of TEMPOH with 3. Complex 3 in $\mathrm{CH}_{2} \mathrm{Cl}_{2}(1.0 \mathrm{mM})$ was treated with 1.2 equiv TEMPOH at $-90{ }^{\circ} \mathrm{C}$ for one hour. The yield of TEMPO ${ }^{\circ}$ is estimated as $90 \%$ by the double integration of its EPR signal. 


\section{Resonance Raman Measurements}

Resonance Raman spectra were recorded on a TriVista 555 triple monochromator equipped with a liquid-nitrogen-cooled Roper Scientific 400BR Excelon CCD camera. An excitation wavelength of $457 \mathrm{~nm}$ and $5 \mathrm{~mW} / 10 \mathrm{~mW} / 50 \mathrm{~mW}$ from a cobalt solid state laser was used. The solution of a sample was packed into a quartz EPR tube and measured in an EPR quartz finger Dewar which were cooled with liquid nitrogen. The Raman signal was collected in a $150^{\circ}$ backscattering geometry with a $100 \mathrm{~mm}$ diameter f/1.5 lens and focused onto the entrance slit of a spectrograph with a $100 \mathrm{~mm}$ diameter $\mathrm{f} / 4$ lens. The scattered light was dispersed with a grating of $1,800 \mathrm{~mm}^{-1}$ and further with two filter prestages of $900 \mathrm{~mm}^{-1}$. The slit widths at the first and third stages amounted to $100 \mu \mathrm{m}$, thus providing a spectral resolution at the CCD camera of about $0.8 \mathrm{~cm}^{-1}$. Spectra were collected for about $30 \mathrm{~min}$ for a given wavelength and spectral window. Calibration of the Raman shifts has been achieved to an accuracy of $1 \mathrm{~cm}^{-1}$ by using $\mathrm{Na}_{2} \mathrm{SO}_{4}$ as well as the solvent signals as references.

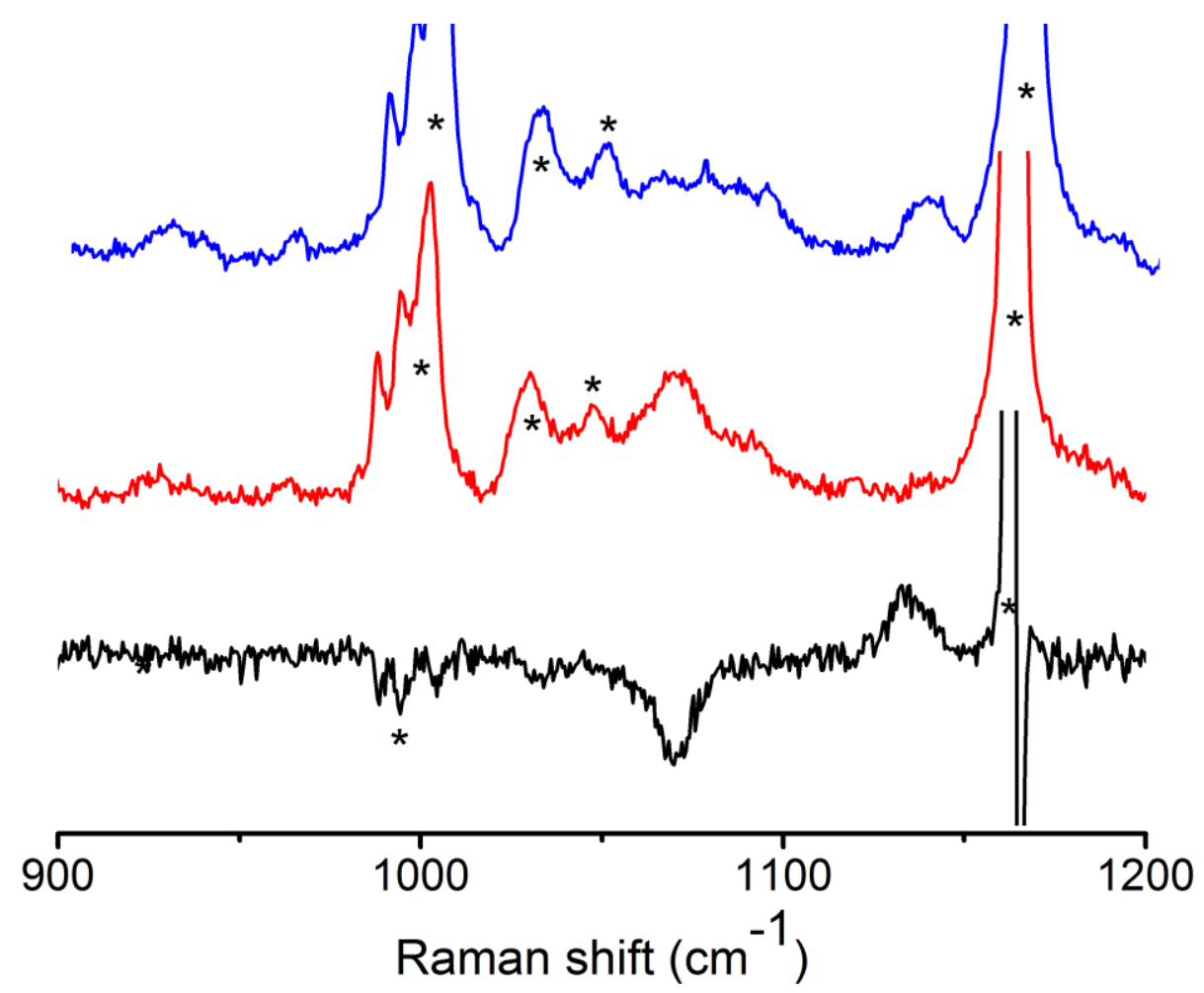

Figure S15. Resonance Raman spectra of $\mathrm{Co}(\mathrm{BDPP})\left(\mathrm{O}_{2}\right)(3)(7.5 \mathrm{mM})$ in DCM $\left(\lambda_{\mathrm{ex}}\right.$ $457 \mathrm{~nm}, 10 \mathrm{~mW}, 77 \mathrm{~K}$, blue line: $\operatorname{Co}(\mathrm{BDPP})\left({ }^{16} \mathrm{O}_{2}\right)$, red line: $\operatorname{Co}(\mathrm{BDPP})\left({ }^{18} \mathrm{O}_{2}\right)$, black line: spectra difference $\operatorname{Co}(\mathrm{BDPP})\left({ }^{16} \mathrm{O}_{2}\right)-\mathrm{Co}(\mathrm{BDPP})\left({ }^{18} \mathrm{O}_{2}\right)$. Asterisks denote solvent peaks. 


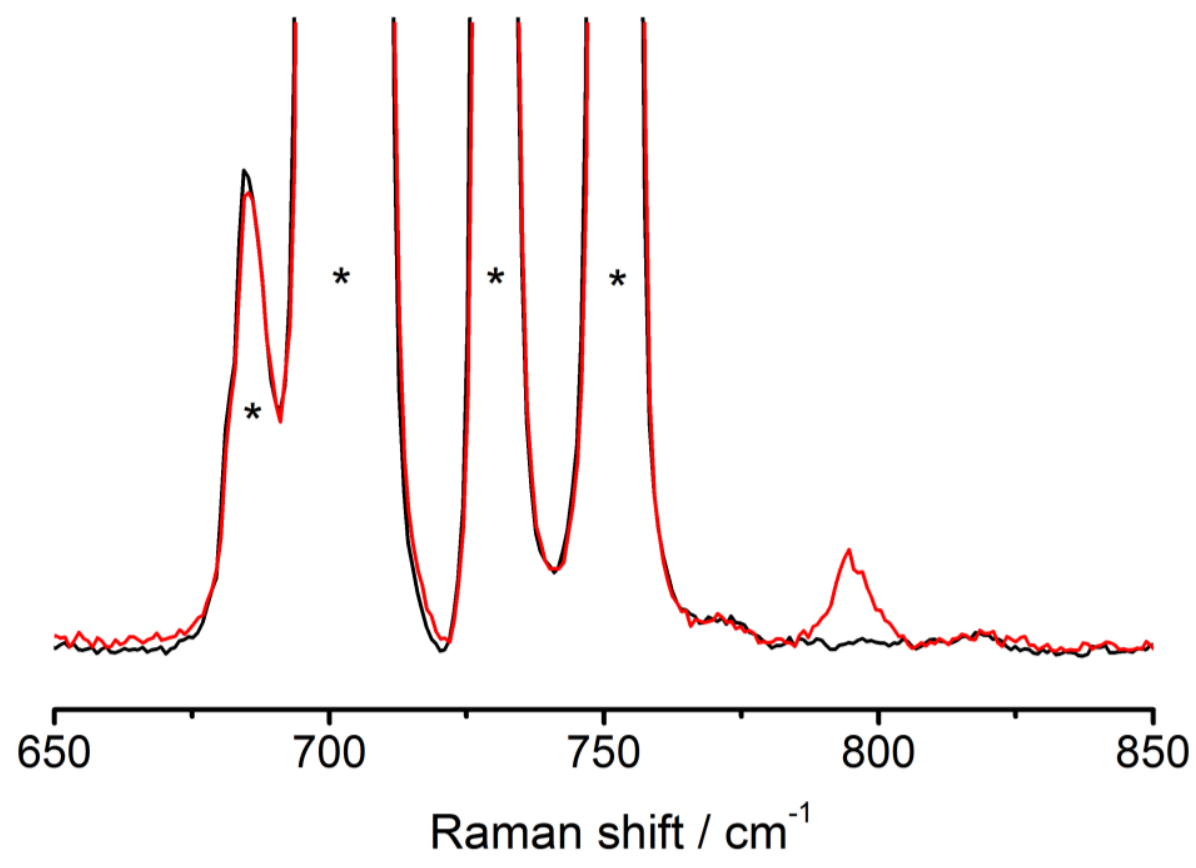

Figure S16. Resonance Raman spectra of Co(BDPP) $\left({ }^{16} \mathrm{OOH}\right)(4)(7.5 \mathrm{mM})$ in DCM $\left(\lambda_{\text {ex }} 457 \mathrm{~nm}, 5 \mathrm{~mW}, 77 \mathrm{~K}\right.$, red line: $\mathrm{Co}(\mathrm{BDPP})\left({ }^{16} \mathrm{OOH}\right)$, black line: DCM). Asterisks denote solvent peaks.

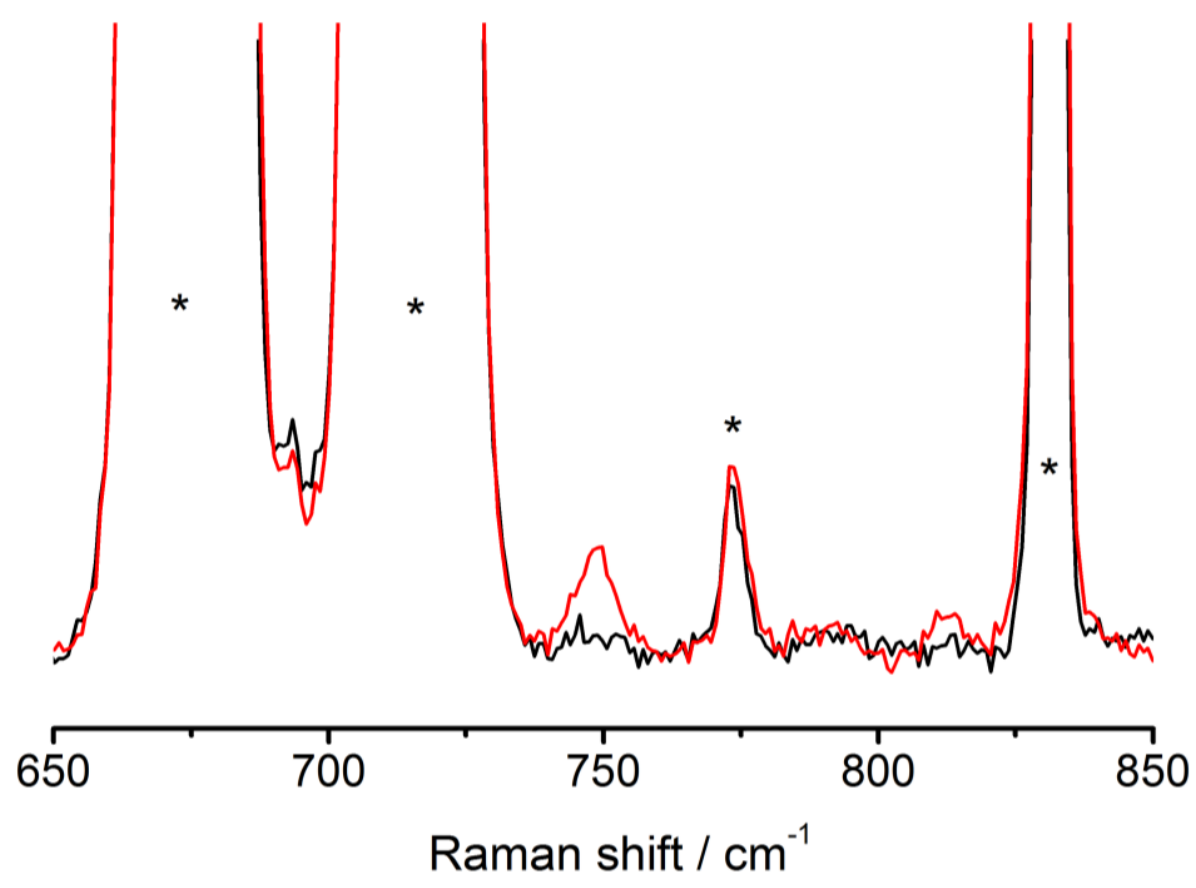

Figure S17. Resonance Raman spectra of Co(BDPP) $\left({ }^{18} \mathrm{OOH}\right)(4)(3.5 \mathrm{mM})$ in DCM$\mathrm{d}_{2}\left(\lambda_{\mathrm{ex}} 457 \mathrm{~nm}, 50 \mathrm{~mW}, 77 \mathrm{~K}\right.$, red line: $\mathrm{Co}(\mathrm{BDPP})\left({ }^{18} \mathrm{OOH}\right)$, black line: DCM-d $\left.\mathrm{d}_{2}\right)$. Asterisks denote solvent peaks. 
Table S4. The O-O distance of metal-hydroperoxo complexes.

\begin{tabular}{ccc}
\hline Complexes $^{\mathrm{a}}$ & $\mathrm{O}-\mathrm{O}$ distance $(\AA)$ & reference \\
\hline $\mathrm{Co}(\mathrm{BDPP})(\mathrm{OOH})(4)$ & $1.497(3)$ & this work \\
$\mathrm{Lig}_{\mathrm{Ph}}(\mathrm{iso}) \mathrm{Ni}(\mathrm{OOH})$ & $1.492(2)$ & $\mathrm{S} 5$ \\
$\left(\mathrm{Tp}^{\mathrm{iPr} 2}\right)\left(\mathrm{Ph}_{3} \mathrm{P}\right) \mathrm{Pd}(\mathrm{OOH})$ & $1.463(9)$ & $\mathrm{S} 6$ \\
$\left.{ }^{t \mathrm{Bu}} \mathrm{PCP}\right) \mathrm{Pd}(\mathrm{OOH})$ & $1.470(4)$ & $\mathrm{S} 7$ \\
$\mathrm{Cs}_{2} \mathrm{Sn}(\mathrm{OOH})_{6}$ & $1.482(2)$ & $\mathrm{S} 8$ \\
{$\left[\mathrm{~L}^{\mathrm{et}} \mathrm{Cu}_{2}(\mathrm{OOH})\right](\mathrm{OTf})\left(\mathrm{BPh}_{4}\right)$} & $1.462(3)$ & $\mathrm{S} 9$ \\
$\mathrm{~L}^{2}\left(\mathrm{H}_{2} \mathrm{O}\right) \mathrm{Co}(\mathrm{OOH})^{2+}$ & $1.397(4)$ & $\mathrm{S} 10$ \\
\hline
\end{tabular}

${ }^{\mathrm{a}} \mathrm{L}^{\mathrm{et}}=\mathrm{Pz}^{\mathrm{et}} \mathrm{TACN} ; \mathrm{L}^{2}=$ meso-5,7,7,12,14,14-Me 6 -[14]aneN 4 . 


\section{Computational Details.}

The initial coordinates for the geometry optimizations of $\mathbf{1}, \mathbf{4}^{\prime}$ and 4 were taken or modified from the corresponding single-crystal X-ray crystallography data. Owing to the lack of crystal structure of $\mathbf{3}$, the initial coordinates of $\mathbf{3}$ were obtained by removing the hydrogen atom of hydroperoxo ligand in $\mathbf{4}$ and subsequently optimized with a doublet state (based on EPR assignment). All density functional theory (DFT) calculations were conducted with TZVP basis sets ${ }^{\mathrm{S} 5}$ for $\mathrm{Co}, \mathrm{N}$, and $\mathrm{O}$ and $6-31 \mathrm{G}^{*}$ basis sets $^{\mathrm{S} 6}$ for $\mathrm{C}$ and $\mathrm{H}$ (ultrafine integration grid and tight $\mathrm{SCF}$ criteria) by Gaussian 09 Version E01. ${ }^{\mathrm{S} 7} \mathrm{BP} 86$ functional ${ }^{\mathrm{S} 8}$ was chosen to perform the geometry optimization of $\mathbf{1 , 3}$ and $\mathbf{4}^{\prime}$, while meta-GGA functional TPSS ${ }^{\mathrm{S} 9}$ was used to optimize the geometry of 4 in order to reproduce the experimental data. The vibrational analysis verified that the optimized DFT structures of $\mathbf{1}, \mathbf{3}, \mathbf{4}^{\prime}$ and $\mathbf{4}$ are all local minima on the potential energy hypersurface. The BP86 functional was employed in the single-point calculations for the d-manifold splitting patterns of $\mathbf{1}, \mathbf{3}, \mathbf{4}^{\prime}$ and $\mathbf{4}$ as well as the frequency calculations for $v_{\mathrm{O}-\mathrm{O}}$ of $\mathbf{3}$ and $\mathbf{4}$, with a $\mathrm{PCM}$ solvent correction $^{\mathrm{S} 10}$ with the solvent used in experiments, in order to compare the relative orbital energies and reproduce the experimental observations. The population analysis and orbital contour plots were done by using the programs QMForge ${ }^{\mathrm{S} 11}$ and Avogadro, ${ }^{\mathrm{S} 12}$ respectively.

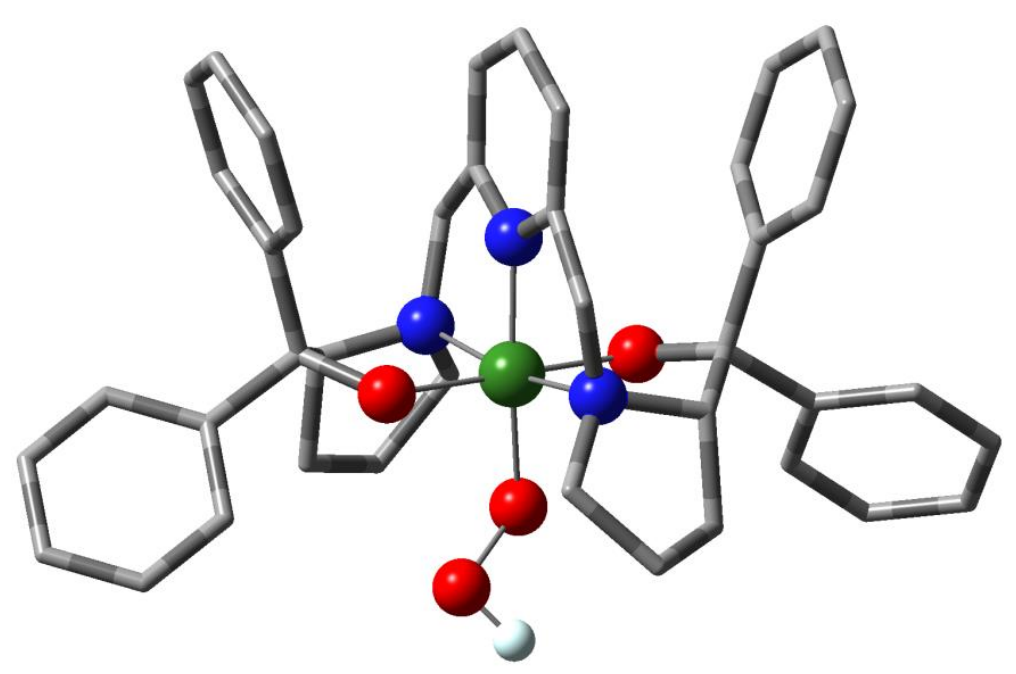

Figure S18. Optimized isomeric structure of $\mathrm{Co}(\mathrm{BDPP})(\mathrm{OOH})\left(4^{\prime}\right)$. Lacking of intramolecular hydrogen bond between the hydroperoxo proton and an oxygen within $\mathrm{BDPP}^{2-}$ ligand would make the potential energy ca. $6 \mathrm{kcal} / \mathrm{mol}$ higher. 
Table S5. Cartesian coordinates of optimized 1

\begin{tabular}{|c|c|c|c|}
\hline Co & 0.00000 & 0.00000 & 0.00000 \\
\hline $\mathrm{O}$ & 0.00031 & 1.43416 & 1.26581 \\
\hline $\mathrm{O}$ & -0.09429 & -1.76503 & 0.72871 \\
\hline $\mathrm{N}$ & -2.05562 & 0.79039 & -0.42196 \\
\hline $\mathrm{N}$ & 0.09856 & 0.33173 & -1.97858 \\
\hline $\mathrm{N}$ & 2.10136 & -0.64091 & -0.45653 \\
\hline $\mathrm{C}$ & -0.83793 & 1.30314 & -3.96029 \\
\hline $\mathrm{C}$ & -0.87187 & 1.06034 & -2.58114 \\
\hline $\mathrm{C}$ & -1.90287 & 1.63551 & -1.62572 \\
\hline $\mathrm{C}$ & -3.07740 & -0.27035 & -0.59151 \\
\hline $\mathrm{C}$ & -3.26350 & -0.83729 & 0.82360 \\
\hline $\mathrm{C}$ & -2.89761 & 0.34590 & 1.76620 \\
\hline $\mathrm{C}$ & -2.39689 & 1.49931 & 0.85363 \\
\hline $\mathrm{C}$ & -2.45554 & 3.29647 & 3.40892 \\
\hline $\mathrm{C}$ & -2.63839 & 3.52937 & 4.78090 \\
\hline $\mathrm{C}$ & -1.72245 & 3.01600 & 5.71392 \\
\hline $\mathrm{C}$ & -0.62753 & 2.26540 & 5.25866 \\
\hline $\mathrm{C}$ & -0.45048 & 2.02805 & 3.88558 \\
\hline $\mathrm{C}$ & -1.36021 & 2.53988 & 2.94166 \\
\hline $\mathrm{C}$ & -1.91421 & 4.53767 & 0.39439 \\
\hline $\mathrm{C}$ & -1.62445 & 5.78532 & -0.18382 \\
\hline $\mathrm{C}$ & -0.29434 & 6.16361 & -0.42290 \\
\hline $\mathrm{C}$ & 0.74043 & 5.27804 & -0.08036 \\
\hline $\mathrm{C}$ & 0.44720 & 4.03027 & 0.49051 \\
\hline $\mathrm{C}$ & -0.88370 & 3.63360 & 0.73902 \\
\hline $\mathrm{C}$ & -1.12635 & 2.25037 & 1.42619 \\
\hline $\mathrm{C}$ & 0.23515 & 0.79239 & -4.71070 \\
\hline $\mathrm{C}$ & 1.23886 & 0.04721 & -4.06820 \\
\hline $\mathrm{C}$ & 1.13499 & -0.17491 & -2.68908 \\
\hline $\mathrm{C}$ & 2.07916 & -1.04560 & -1.87862 \\
\hline $\mathrm{C}$ & 3.11538 & 0.40267 & -0.17282 \\
\hline $\mathrm{C}$ & 3.15712 & 0.47421 & 1.36067 \\
\hline $\mathrm{C}$ & 2.72387 & -0.94603 & 1.82703 \\
\hline $\mathrm{C}$ & 2.33133 & -1.73144 & 0.54531 \\
\hline $\mathrm{C}$ & 2.17002 & -4.27421 & 2.36255 \\
\hline $\mathrm{C}$ & 2.22628 & -4.94494 & 3.59420 \\
\hline $\mathrm{C}$ & 1.22499 & -4.74008 & 4.55777 \\
\hline
\end{tabular}




\begin{tabular}{|c|c|c|c|}
\hline $\mathrm{C}$ & 0.17273 & -3.85518 & 4.27622 \\
\hline $\mathrm{C}$ & 0.12234 & -3.17993 & 3.04555 \\
\hline $\mathrm{C}$ & 1.11846 & -3.37975 & 2.07170 \\
\hline $\mathrm{C}$ & 1.94034 & -4.44116 & -0.92944 \\
\hline $\mathrm{C}$ & 1.72454 & -5.42723 & -1.90729 \\
\hline $\mathrm{C}$ & 0.42753 & -5.68994 & -2.37427 \\
\hline $\mathrm{C}$ & -0.64877 & -4.95273 & -1.85417 \\
\hline $\mathrm{C}$ & -0.42892 & -3.96425 & -0.88294 \\
\hline $\mathrm{C}$ & 0.86784 & -3.68681 & -0.40138 \\
\hline $\mathrm{C}$ & 1.02445 & -2.60770 & 0.71884 \\
\hline $\mathrm{H}$ & -1.63321 & 1.88717 & -4.43565 \\
\hline $\mathrm{H}$ & -2.87551 & 1.79341 & -2.14064 \\
\hline $\mathrm{H}$ & -1.54280 & 2.62913 & -1.30241 \\
\hline $\mathrm{H}$ & -4.02247 & 0.17927 & -0.97716 \\
\hline $\mathrm{H}$ & -2.72426 & -1.01326 & -1.32836 \\
\hline $\mathrm{H}$ & -4.29301 & -1.20361 & 0.97565 \\
\hline $\mathrm{H}$ & -2.56535 & -1.67470 & 0.98402 \\
\hline $\mathrm{H}$ & -3.75131 & 0.68537 & 2.37497 \\
\hline $\mathrm{H}$ & -2.09564 & 0.04846 & 2.46054 \\
\hline $\mathrm{H}$ & -3.22748 & 2.21387 & 0.66652 \\
\hline $\mathrm{H}$ & -3.17754 & 3.71899 & 2.70153 \\
\hline $\mathrm{H}$ & -3.49895 & 4.11809 & 5.12045 \\
\hline $\mathrm{H}$ & -1.86212 & 3.20114 & 6.78526 \\
\hline $\mathrm{H}$ & 0.09484 & 1.85747 & 5.97588 \\
\hline $\mathrm{H}$ & 0.39312 & 1.43800 & 3.51643 \\
\hline $\mathrm{H}$ & -2.96469 & 4.27390 & 0.56217 \\
\hline $\mathrm{H}$ & -2.44571 & 6.46271 & -0.44667 \\
\hline $\mathrm{H}$ & -0.06757 & 7.13773 & -0.87112 \\
\hline $\mathrm{H}$ & 1.78513 & 5.56060 & -0.25783 \\
\hline $\mathrm{H}$ & 1.24555 & 3.33145 & 0.75673 \\
\hline $\mathrm{H}$ & 0.28905 & 0.97422 & -5.78936 \\
\hline $\mathrm{H}$ & 2.08623 & -0.36169 & -4.62882 \\
\hline $\mathrm{H}$ & 3.09926 & -1.04151 & -2.32083 \\
\hline $\mathrm{H}$ & 1.70714 & -2.08493 & -1.93292 \\
\hline $\mathrm{H}$ & 4.10051 & 0.09082 & -0.59273 \\
\hline $\mathrm{H}$ & 2.81955 & 1.35019 & -0.65686 \\
\hline $\mathrm{H}$ & 4.16122 & 0.75566 & 1.72089 \\
\hline $\mathrm{H}$ & 2.43275 & 1.22389 & 1.71787 \\
\hline
\end{tabular}




$\begin{array}{lrrr}\mathrm{H} & 3.52170 & -1.47811 & 2.37018 \\ \mathrm{H} & 1.85481 & -0.87908 & 2.50071 \\ \mathrm{H} & 3.18749 & -2.35926 & 0.21630 \\ \mathrm{H} & 2.95603 & -4.46244 & 1.62302 \\ \mathrm{H} & 3.05471 & -5.63368 & 3.79862 \\ \mathrm{H} & 1.26570 & -5.26710 & 5.51805 \\ \mathrm{H} & -0.61530 & -3.68483 & 5.01960 \\ \mathrm{H} & -0.68682 & -2.48127 & 2.81478 \\ \mathrm{H} & 2.96723 & -4.25981 & -0.59195 \\ \mathrm{H} & 2.57753 & -5.99130 & -2.30309 \\ \mathrm{H} & 0.25819 & -6.46071 & -3.13485 \\ \mathrm{H} & -1.66870 & -5.14897 & -2.20625 \\ \mathrm{H} & -1.26002 & -3.38201 & -0.47443\end{array}$


Table S6. Cartesian coordinates of optimized 3

\begin{tabular}{lrrr}
\hline Co & 0.00000 & 0.00000 & 0.00000 \\
$\mathrm{O}$ & -0.21777 & -0.44532 & 1.82598 \\
$\mathrm{O}$ & 0.31947 & 0.28946 & 2.77315 \\
$\mathrm{O}$ & 0.16082 & 1.88461 & 0.36019 \\
$\mathrm{O}$ & -0.19549 & -1.89565 & -0.33029 \\
$\mathrm{~N}$ & -1.97441 & 0.35971 & -0.28588 \\
$\mathrm{~N}$ & 0.13943 & 0.31977 & -1.86926 \\
$\mathrm{~N}$ & 1.99781 & -0.30279 & -0.10216 \\
$\mathrm{C}$ & -0.92278 & 0.70739 & -3.96244 \\
$\mathrm{C}$ & -0.98635 & 0.46088 & -2.58591 \\
$\mathrm{C}$ & -2.22756 & 0.21904 & -1.76297 \\
$\mathrm{C}$ & -2.91810 & -0.56432 & 0.44390 \\
$\mathrm{C}$ & -3.16333 & 0.04644 & 1.83543 \\
$\mathrm{C}$ & -2.59346 & 1.48640 & 1.76522 \\
$\mathrm{C}$ & -2.24037 & 1.75111 & 0.28629 \\
$\mathrm{C}$ & -1.95039 & 4.90673 & 0.98232 \\
$\mathrm{C}$ & -2.00357 & 5.93281 & 1.93886 \\
$\mathrm{C}$ & -1.13765 & 5.91414 & 3.04460 \\
$\mathrm{C}$ & -0.22544 & 4.85663 & 3.18551 \\
$\mathrm{C}$ & -0.17941 & 3.82405 & 2.23444 \\
$\mathrm{C}$ & -1.04164 & 3.83721 & 1.12114 \\
$\mathrm{C}$ & -2.03569 & 3.68006 & -2.09845 \\
$\mathrm{C}$ & -1.89367 & 4.35335 & -3.32566 \\
$\mathrm{C}$ & -0.62050 & 4.70658 & -3.79474 \\
$\mathrm{C}$ & 0.50811 & 4.38309 & -3.02110 \\
$\mathrm{C}$ & 0.36046 & 3.70731 & -1.80220 \\
$\mathrm{C}$ & -0.91129 & 3.33254 & -1.31924 \\
$\mathrm{C}$ & -0.97672 & 2.66282 & 0.09130 \\
$\mathrm{C}$ & 0.34329 & 0.77636 & -4.56687 \\
$\mathrm{C}$ & 1.50561 & 0.61263 & -3.79509 \\
$\mathrm{C}$ & 1.36099 & 0.39442 & -2.42007 \\
$\mathrm{C}$ & 2.45897 & 0.33216 & -1.38653 \\
$\mathrm{C}$ & 2.77654 & 0.28780 & 1.06568 \\
$\mathrm{C}$ & 3.22441 & -0.88837 & 1.95465 \\
$\mathrm{C}$ & 2.39650 & -2.08877 & 1.46472 \\
$\mathrm{C}$ & & -1.82290 & -0.03532 \\
$\mathrm{C}$ & -5.02723 & -0.45488 \\
& & & \\
& & & \\
& & &
\end{tabular}




\begin{tabular}{|c|c|c|c|}
\hline $\mathrm{C}$ & 1.78439 & -6.30333 & 0.12743 \\
\hline $\mathrm{C}$ & 0.80081 & -6.60172 & 1.08475 \\
\hline $\mathrm{C}$ & -0.12055 & -5.60971 & 1.45523 \\
\hline $\mathrm{C}$ & -0.05686 & -4.33008 & 0.87998 \\
\hline $\mathrm{C}$ & 0.92463 & -4.02196 & -0.08123 \\
\hline $\mathrm{C}$ & 2.33586 & -2.85843 & -2.92442 \\
\hline $\mathrm{C}$ & 2.36673 & -3.09487 & -4.31107 \\
\hline $\mathrm{C}$ & 1.17217 & -3.24457 & -5.02945 \\
\hline $\mathrm{C}$ & -0.05317 & -3.15927 & -4.34540 \\
\hline $\mathrm{C}$ & -0.07737 & -2.91807 & -2.96504 \\
\hline $\mathrm{C}$ & 1.11368 & -2.75335 & -2.22657 \\
\hline $\mathrm{C}$ & 0.98011 & -2.57767 & -0.67884 \\
\hline $\mathrm{H}$ & -1.83714 & 0.84171 & -4.54795 \\
\hline $\mathrm{H}$ & -2.52849 & -0.83174 & -1.92823 \\
\hline $\mathrm{H}$ & -3.07103 & 0.86610 & -2.07290 \\
\hline $\mathrm{H}$ & -3.86400 & -0.61105 & -0.13347 \\
\hline $\mathrm{H}$ & -2.45563 & -1.56495 & 0.45167 \\
\hline $\mathrm{H}$ & -4.24305 & 0.04018 & 2.06566 \\
\hline $\mathrm{H}$ & -2.64735 & -0.53272 & 2.61587 \\
\hline $\mathrm{H}$ & -3.30802 & 2.24584 & 2.12157 \\
\hline $\mathrm{H}$ & -1.68719 & 1.56879 & 2.38293 \\
\hline $\mathrm{H}$ & -3.13134 & 2.15427 & -0.23614 \\
\hline $\mathrm{H}$ & -2.61385 & 4.95538 & 0.11164 \\
\hline $\mathrm{H}$ & -2.71901 & 6.75422 & 1.81275 \\
\hline $\mathrm{H}$ & -1.17339 & 6.71909 & 3.78796 \\
\hline $\mathrm{H}$ & 0.45450 & 4.82907 & 4.04543 \\
\hline $\mathrm{H}$ & 0.51098 & 2.98228 & 2.34031 \\
\hline $\mathrm{H}$ & -3.04843 & 3.43754 & -1.75535 \\
\hline $\mathrm{H}$ & -2.78631 & 4.60727 & -3.91010 \\
\hline $\mathrm{H}$ & -0.50785 & 5.23685 & -4.74734 \\
\hline $\mathrm{H}$ & 1.50906 & 4.66799 & -3.36723 \\
\hline $\mathrm{H}$ & 1.23191 & 3.46085 & -1.18668 \\
\hline $\mathrm{H}$ & 0.42452 & 0.95822 & -5.64337 \\
\hline $\mathrm{H}$ & 2.49880 & 0.65555 & -4.25194 \\
\hline $\mathrm{H}$ & 2.72736 & 1.37543 & -1.14188 \\
\hline $\mathrm{H}$ & 3.36847 & -0.17395 & -1.76527 \\
\hline $\mathrm{H}$ & 3.63921 & 0.85550 & 0.67364 \\
\hline $\mathrm{H}$ & 2.09615 & 0.98162 & 1.58689 \\
\hline
\end{tabular}




$\begin{array}{lrrr}\mathrm{H} & 4.30506 & -1.08278 & 1.82175 \\ \mathrm{H} & 3.04667 & -0.67142 & 3.02024 \\ \mathrm{H} & 2.90175 & -3.05376 & 1.62861 \\ \mathrm{H} & 1.41691 & -2.12577 & 1.96590 \\ \mathrm{H} & 3.14740 & -2.04927 & -0.56201 \\ \mathrm{H} & 2.59733 & -4.82351 & -1.22065 \\ \mathrm{H} & 2.50741 & -7.06959 & -0.17668 \\ \mathrm{H} & 0.75171 & -7.60035 & 1.53410 \\ \mathrm{H} & -0.89433 & -5.82994 & 2.20045 \\ \mathrm{H} & -0.76067 & -3.54333 & 1.16566 \\ \mathrm{H} & 3.29132 & -2.76480 & -2.39483 \\ \mathrm{H} & 3.33229 & -3.16834 & -4.82594 \\ \mathrm{H} & 1.19413 & -3.43499 & -6.10860 \\ \mathrm{H} & -0.99536 & -3.29013 & -4.89129 \\ \mathrm{H} & -1.02593 & -2.86042 & -2.42114\end{array}$


Table S7. Cartesian coordinates of optimized 4

\begin{tabular}{|c|c|c|c|}
\hline Co & 0.00000 & 0.00000 & 0.00000 \\
\hline $\mathrm{O}$ & 0.66620 & 1.20430 & 2.42960 \\
\hline $\mathrm{O}$ & 0.00000 & 0.00000 & 1.87850 \\
\hline $\mathrm{O}$ & 0.00040 & 1.94770 & 0.00640 \\
\hline $\mathrm{O}$ & -0.09660 & -1.90990 & 0.07710 \\
\hline $\mathrm{N}$ & -2.00980 & 0.14680 & -0.06700 \\
\hline $\mathrm{N}$ & -0.12380 & -0.09580 & -1.88410 \\
\hline $\mathrm{N}$ & 1.97980 & -0.22440 & -0.30490 \\
\hline $\mathrm{C}$ & -0.20620 & 4.49900 & 0.98660 \\
\hline $\mathrm{C}$ & -0.27730 & 5.75760 & 1.60160 \\
\hline $\mathrm{C}$ & -1.48380 & 6.46710 & 1.62630 \\
\hline $\mathrm{C}$ & -2.62030 & 5.91040 & 1.02190 \\
\hline C & -2.54560 & 4.65770 & 0.40190 \\
\hline $\mathrm{C}$ & -1.34050 & 3.92880 & 0.38640 \\
\hline $\mathrm{C}$ & -2.58340 & 2.98060 & -2.51770 \\
\hline $\mathrm{C}$ & -2.62390 & 3.35860 & -3.86850 \\
\hline $\mathrm{C}$ & -1.43880 & 3.63560 & -4.56040 \\
\hline $\mathrm{C}$ & -0.21360 & 3.53500 & -3.88500 \\
\hline $\mathrm{C}$ & -0.17760 & 3.15370 & -2.53920 \\
\hline $\mathrm{C}$ & -1.35890 & 2.85760 & -1.83300 \\
\hline $\mathrm{C}$ & -1.24140 & 2.54300 & -0.31220 \\
\hline $\mathrm{C}$ & -2.36660 & 1.59940 & 0.22680 \\
\hline $\mathrm{C}$ & -2.53880 & 1.65410 & 1.75970 \\
\hline $\mathrm{C}$ & -2.91430 & 0.22390 & 2.21790 \\
\hline C & -2.73520 & -0.67120 & 0.98120 \\
\hline $\mathrm{C}$ & -2.43920 & -0.33980 & -1.42670 \\
\hline $\mathrm{C}$ & -1.33670 & -0.21620 & -2.44770 \\
\hline $\mathrm{C}$ & -1.46490 & -0.32160 & -3.83430 \\
\hline $\mathrm{C}$ & -0.29850 & -0.33440 & -4.61180 \\
\hline $\mathrm{C}$ & 0.95790 & -0.24140 & -3.99780 \\
\hline $\mathrm{C}$ & 1.00680 & -0.11420 & -2.60790 \\
\hline C & 2.23050 & 0.10350 & -1.75700 \\
\hline $\mathrm{C}$ & 2.93690 & 0.62240 & 0.51920 \\
\hline $\mathrm{C}$ & 3.34300 & -0.20720 & 1.75140 \\
\hline $\mathrm{C}$ & 2.59250 & -1.54640 & 1.59960 \\
\hline $\mathrm{C}$ & 2.29410 & -1.66950 & 0.09790 \\
\hline $\mathrm{C}$ & -0.15090 & -3.48130 & -2.27130 \\
\hline
\end{tabular}




\begin{tabular}{|c|c|c|c|}
\hline $\mathrm{C}$ & -0.23400 & -4.01090 & -3.56360 \\
\hline $\mathrm{C}$ & 0.92580 & -4.18350 & -4.33460 \\
\hline $\mathrm{C}$ & 2.16530 & -3.82990 & -3.78970 \\
\hline $\mathrm{C}$ & 2.24330 & -3.30430 & -2.48980 \\
\hline $\mathrm{C}$ & 1.08580 & -3.10740 & -1.71100 \\
\hline $\mathrm{C}$ & 2.07890 & -4.91820 & 0.40890 \\
\hline $\mathrm{C}$ & 2.15750 & -6.02700 & 1.26230 \\
\hline $\mathrm{C}$ & 1.32390 & -6.11360 & 2.38580 \\
\hline $\mathrm{C}$ & 0.41680 & -5.07850 & 2.64860 \\
\hline $\mathrm{C}$ & 0.34470 & -3.96540 & 1.80010 \\
\hline $\mathrm{C}$ & 1.17500 & -3.87140 & 0.66990 \\
\hline $\mathrm{C}$ & 1.08730 & -2.60430 & -0.23570 \\
\hline $\mathrm{H}$ & 0.37870 & 1.86050 & 1.72810 \\
\hline $\mathrm{H}$ & 0.73240 & 3.95020 & 0.96370 \\
\hline $\mathrm{H}$ & 0.61460 & 6.18000 & 2.06430 \\
\hline $\mathrm{H}$ & -1.54000 & 7.44290 & 2.10750 \\
\hline $\mathrm{H}$ & -3.56590 & 6.45230 & 1.03010 \\
\hline $\mathrm{H}$ & -3.43650 & 4.25000 & -0.07610 \\
\hline $\mathrm{H}$ & -3.52680 & 2.79190 & -2.00550 \\
\hline $\mathrm{H}$ & -3.58590 & 3.44230 & -4.37470 \\
\hline $\mathrm{H}$ & -1.46930 & 3.93440 & -5.60780 \\
\hline $\mathrm{H}$ & 0.71650 & 3.76140 & -4.40720 \\
\hline $\mathrm{H}$ & 0.76770 & 3.08430 & -2.00430 \\
\hline $\mathrm{H}$ & -3.33740 & 1.79540 & -0.25620 \\
\hline $\mathrm{H}$ & -1.60390 & 1.96170 & 2.23570 \\
\hline $\mathrm{H}$ & -3.30580 & 2.39300 & 2.01970 \\
\hline $\mathrm{H}$ & -3.95280 & 0.17040 & 2.57260 \\
\hline $\mathrm{H}$ & -2.24840 & -0.09520 & 3.02340 \\
\hline $\mathrm{H}$ & -3.71370 & -0.95700 & 0.56180 \\
\hline $\mathrm{H}$ & -2.13780 & -1.57240 & 1.15060 \\
\hline $\mathrm{H}$ & -3.36330 & 0.16790 & -1.74200 \\
\hline $\mathrm{H}$ & -2.65830 & -1.41020 & -1.31490 \\
\hline $\mathrm{H}$ & -2.44730 & -0.39840 & -4.29500 \\
\hline $\mathrm{H}$ & -0.36840 & -0.42550 & -5.69400 \\
\hline $\mathrm{H}$ & 1.87350 & -0.27270 & -4.58380 \\
\hline $\mathrm{H}$ & 3.10410 & -0.45350 & -2.12760 \\
\hline $\mathrm{H}$ & 2.47120 & 1.17500 & -1.79100 \\
\hline $\mathrm{H}$ & 3.81240 & 0.84450 & -0.11100 \\
\hline
\end{tabular}




$\begin{array}{lrrr}\mathrm{H} & 2.42390 & 1.55580 & 0.76280 \\ \mathrm{H} & 4.43170 & -0.35750 & 1.75650 \\ \mathrm{H} & 3.05190 & 0.30230 & 2.67380 \\ \mathrm{H} & 3.17640 & -2.40490 & 1.95020 \\ \mathrm{H} & 1.64320 & -1.50070 & 2.14220 \\ \mathrm{H} & 3.21160 & -1.96550 & -0.43740 \\ \mathrm{H} & -1.04480 & -3.35420 & -1.66340 \\ \mathrm{H} & -1.20470 & -4.29720 & -3.96910 \\ \mathrm{H} & 0.86370 & -4.59710 & -5.34080 \\ \mathrm{H} & 3.07830 & -3.96800 & -4.36980 \\ \mathrm{H} & 3.22790 & -3.05900 & -2.09130 \\ \mathrm{H} & 2.71800 & -4.88140 & -0.47270 \\ \mathrm{H} & 2.86510 & -6.82650 & 1.04240 \\ \mathrm{H} & 1.37960 & -6.97900 & 3.04600 \\ \mathrm{H} & -0.23630 & -5.13340 & 3.51980 \\ \mathrm{H} & -0.34500 & -3.14940 & 2.00060\end{array}$


Table S8. Cartesian coordinates of optimized 4'

\begin{tabular}{|c|c|c|c|}
\hline $\mathrm{Co}$ & 0.00000 & 0.00000 & 0.00000 \\
\hline $\mathrm{O}$ & -0.28870 & -0.03974 & 1.87616 \\
\hline $\mathrm{O}$ & 0.02824 & 1.20881 & 2.63171 \\
\hline $\mathrm{O}$ & -0.11518 & 1.91540 & -0.17802 \\
\hline $\mathrm{O}$ & 0.10061 & -1.92461 & 0.18249 \\
\hline $\mathrm{N}$ & -1.98893 & -0.03362 & -0.36115 \\
\hline $\mathrm{N}$ & 0.16549 & -0.18389 & -1.86250 \\
\hline $\mathrm{N}$ & 2.01100 & 0.00000 & 0.00000 \\
\hline $\mathrm{C}$ & -0.84511 & -0.60040 & -3.97705 \\
\hline $\mathrm{C}$ & -0.93533 & -0.44128 & -2.58953 \\
\hline $\mathrm{C}$ & -2.16175 & -0.62671 & -1.73183 \\
\hline $\mathrm{C}$ & -2.79540 & -0.84669 & 0.62911 \\
\hline $\mathrm{C}$ & -3.32103 & 0.12137 & 1.70622 \\
\hline $\mathrm{C}$ & -2.83990 & 1.52521 & 1.27595 \\
\hline $\mathrm{C}$ & -2.46901 & 1.40938 & -0.21328 \\
\hline $\mathrm{C}$ & -2.65488 & 4.64413 & -0.45460 \\
\hline $\mathrm{C}$ & -2.89410 & 5.87910 & 0.16849 \\
\hline $\mathrm{C}$ & -2.08924 & 6.29758 & 1.24085 \\
\hline $\mathrm{C}$ & -1.05041 & 5.46494 & 1.68586 \\
\hline $\mathrm{C}$ & -0.81818 & 4.22418 & 1.07005 \\
\hline $\mathrm{C}$ & -1.61746 & 3.79931 & -0.00845 \\
\hline $\mathrm{C}$ & -2.43351 & 2.59105 & -3.05162 \\
\hline $\mathrm{C}$ & -2.33599 & 2.90877 & -4.41879 \\
\hline $\mathrm{C}$ & -1.10912 & 3.31123 & -4.96520 \\
\hline $\mathrm{C}$ & 0.01755 & 3.39651 & -4.12838 \\
\hline $\mathrm{C}$ & -0.08512 & 3.07342 & -2.76850 \\
\hline $\mathrm{C}$ & -1.30799 & 2.65470 & -2.20240 \\
\hline $\mathrm{C}$ & -1.33969 & 2.40530 & -0.65941 \\
\hline $\mathrm{C}$ & 0.42097 & -0.50959 & -4.57833 \\
\hline $\mathrm{C}$ & 1.55782 & -0.25512 & -3.79343 \\
\hline $\mathrm{C}$ & 1.38711 & -0.08402 & -2.41543 \\
\hline $\mathrm{C}$ & 2.43506 & 0.31944 & -1.40949 \\
\hline $\mathrm{C}$ & 2.62852 & 1.00790 & 0.96326 \\
\hline $\mathrm{C}$ & 3.25944 & 0.19642 & 2.11055 \\
\hline $\mathrm{C}$ & 2.60043 & -1.18864 & 2.00457 \\
\hline $\mathrm{C}$ & 2.43751 & -1.38937 & 0.49067 \\
\hline $\mathrm{C}$ & 2.55288 & -4.61887 & 0.99904 \\
\hline
\end{tabular}




\begin{tabular}{|c|c|c|c|}
\hline $\mathrm{C}$ & 2.64530 & -5.66401 & 1.93220 \\
\hline $\mathrm{C}$ & 1.68030 & -5.79681 & 2.94401 \\
\hline $\mathrm{C}$ & 0.62674 & -4.87153 & 3.01431 \\
\hline $\mathrm{C}$ & 0.54015 & -3.82087 & 2.08663 \\
\hline $\mathrm{C}$ & 1.50229 & -3.68060 & 1.06784 \\
\hline $\mathrm{C}$ & 2.90862 & -3.16218 & -1.96963 \\
\hline $\mathrm{C}$ & 3.06026 & -3.76312 & -3.23289 \\
\hline $\mathrm{C}$ & 1.94676 & -4.28681 & -3.90473 \\
\hline $\mathrm{C}$ & 0.68115 & -4.20665 & -3.29775 \\
\hline $\mathrm{C}$ & 0.53562 & -3.60097 & -2.04231 \\
\hline $\mathrm{C}$ & 1.64209 & -3.05778 & -1.35548 \\
\hline $\mathrm{C}$ & 1.38389 & -2.47810 & 0.07427 \\
\hline $\mathrm{H}$ & -1.74224 & -0.79063 & -4.57365 \\
\hline $\mathrm{H}$ & -2.29523 & -1.71437 & -1.58788 \\
\hline $\mathrm{H}$ & -3.07736 & -0.23326 & -2.21531 \\
\hline $\mathrm{H}$ & -3.63477 & -1.31928 & 0.08136 \\
\hline $\mathrm{H}$ & -2.13037 & -1.63605 & 1.01268 \\
\hline $\mathrm{H}$ & -4.42388 & 0.06752 & 1.75838 \\
\hline $\mathrm{H}$ & -2.91723 & -0.13718 & 2.69673 \\
\hline $\mathrm{H}$ & -3.60974 & 2.30179 & 1.41575 \\
\hline $\mathrm{H}$ & -1.95157 & 1.81231 & 1.85606 \\
\hline $\mathrm{H}$ & -3.38537 & 1.51456 & -0.82932 \\
\hline $\mathrm{H}$ & -3.27502 & 4.34922 & -1.30845 \\
\hline $\mathrm{H}$ & -3.70706 & 6.51996 & -0.19342 \\
\hline $\mathrm{H}$ & -2.27014 & 7.26557 & 1.72273 \\
\hline $\mathrm{H}$ & -0.41646 & 5.77948 & 2.52379 \\
\hline $\mathrm{H}$ & -0.02758 & 3.55354 & 1.41741 \\
\hline $\mathrm{H}$ & -3.41342 & 2.29812 & -2.65659 \\
\hline $\mathrm{H}$ & -3.22807 & 2.84657 & -5.05384 \\
\hline $\mathrm{H}$ & -1.03207 & 3.56516 & -6.02869 \\
\hline $\mathrm{H}$ & 0.98021 & 3.72570 & -4.53819 \\
\hline $\mathrm{H}$ & 0.78351 & 3.14803 & -2.10584 \\
\hline $\mathrm{H}$ & 0.52233 & -0.63927 & -5.66059 \\
\hline $\mathrm{H}$ & 2.55325 & -0.19187 & -4.24271 \\
\hline $\mathrm{H}$ & 2.53082 & 1.41828 & -1.46722 \\
\hline $\mathrm{H}$ & 3.42626 & -0.12308 & -1.62968 \\
\hline $\mathrm{H}$ & 3.38229 & 1.61107 & 0.42707 \\
\hline $\mathrm{H}$ & 1.81278 & 1.66770 & 1.29834 \\
\hline
\end{tabular}




$\begin{array}{lrrr}\mathrm{H} & 4.35381 & 0.11393 & 1.97077 \\ \mathrm{H} & 3.09202 & 0.67872 & 3.08927 \\ \mathrm{H} & 3.20694 & -1.99189 & 2.45174 \\ \mathrm{H} & 1.59835 & -1.19291 & 2.46527 \\ \mathrm{H} & 3.43550 & -1.59836 & 0.05448 \\ \mathrm{H} & 3.29940 & -4.54958 & 0.20010 \\ \mathrm{H} & 3.47033 & -6.38277 & 1.86020 \\ \mathrm{H} & 1.74738 & -6.61761 & 3.66759 \\ \mathrm{H} & -0.13475 & -4.96562 & 3.79799 \\ \mathrm{H} & -0.26793 & -3.08521 & 2.13215 \\ \mathrm{H} & 3.80627 & -2.78165 & -1.46790 \\ \mathrm{H} & 4.05705 & -3.82569 & -3.68607 \\ \mathrm{H} & 2.06358 & -4.76061 & -4.88617 \\ \mathrm{H} & -0.19662 & -4.62597 & -3.80423 \\ \mathrm{H} & -0.44414 & -3.54000 & -1.55749 \\ \mathrm{H} & 0.53421 & 0.81430 & 3.37926\end{array}$




\section{References}

S1. Zhang, Y.-X.; Du, D.-M.; Chen, X.; Lü, S.-F.; Hua, W.-T. Tetrahedron: Asymmetry 2004, 15, 177.

S2. Mader, E. A.; Larsen, A. S.; Mayer, J. M. J. Am. Chem. Soc. 2004, 126, 8066.

S3. Shores, M. P.; Sokol, J. J.; Long, J. R. J. Am. Chem. Soc. 2002, 124, 2279.

S4. Sun, L.; Hernandez-Guzman, J.; Warncke, K. J. Magn. Reson. 2009, $200,21$.

S5. Rettenmeier, C. A.; Wadepohl, H.; Gade. L. H. Angew. Chem. Int. Ed. 2015, 54, 4880.

S6. Miyaji, T.; Kujime, M.; Hikichi, S.; Moro-oka, Y.; Akita, M. Inorg. Chem. 2002, $41,5286$.

S7. Denney, M. C.; Smythe, N. A.; Cetto, K. L.; Kemp, R. A.; Goldberg, K. I. J. Am.Chem. Soc. 2006, 128, 2508.

S8. Churakov, A. V.; Sladkevich, S.; Lev, O.; Tripol' skaya, T. A.; Prikhodchenko. P. V. Inorg. Chem. 2010, 49, 4762.

S9. Kindermann, N.; Dechert, S.; Demeshko, S.; Meyer, F. J. Am. Chem. Soc. 2015, $137,8002$.

S10. Guzei, I. A.; Bakac, A. Inorg. Chem. 2001, 40, 2390.

S11. Schäfer, A.; Huber, C.; Ahlrichs, R. J. Chem. Phys. 1994, 100, 5829.

S12. Hehre, W. J.; Ditchfeld, R.; Pople, J. A. J. Chem. Phys. 1972, 56, 2257.

S13. Gaussian 09, Revision E.01, M. J. Frisch, G. W. Trucks, H. B. Schlegel, G. E. Scuseria, M. A. Robb, J. R. Cheeseman, G. Scalmani, V. Barone, B. Mennucci, G. A. Petersson, H. Nakatsuji, M. Caricato, X. Li, H. P. Hratchian, A. F. Izmaylov, J. Bloino, G. Zheng, J. L. Sonnenberg, M. Hada, M. Ehara, K. Toyota, R. Fukuda, J. Hasegawa, M. Ishida, T. Nakajima, Y. Honda, O. Kitao, H. Nakai, T. Vreven, J. A. Montgomery, Jr., J. E. Peralta, F. Ogliaro, M. Bearpark, J. J. Heyd, E. Brothers, K. N. Kudin, V. N. Staroverov, T. Keith, R. Kobayashi, J. Normand, K. Raghavachari, A. Rendell, J. C. Burant, S. S. Iyengar, J. Tomasi, M. Cossi, N. Rega, J. M. Millam, M. Klene, J. E. Knox, J. B. Cross, V. Bakken, C. Adamo, J. Jaramillo, R. Gomperts, R. E. Stratmann, O. Yazyev, A. J. Austin, R. Cammi, C. Pomelli, J. W. Ochterski, R. L. Martin, K. Morokuma, V. G. Zakrzewski, G. A. Voth, P. Salvador, J. J. Dannenberg, S. Dapprich, A. D. Daniels, O. Farkas, J. B. Foresman, J. V. Ortiz, J. Cioslowski, and D. J. Fox, Gaussian, Inc., Wallingford CT, 2013.

S14. (a) Becke, A. D. Phys. Rev. A 1988, 38, 3098. (b) Perdew, J. P. Phys. Rev. B 1986, 33,8822 .

S15. Tao, J.; Perdew, J. P.; Staroverov, V. N.; Scuseria, G. E. Phys. Rev. Lett. 2003, 91,146401 .

S16. (a) Miertuš, S.; Scrocco, E.; Tomasi, J. Chem. Phys. 1981, 55, 117; (b) Miertuš, S.; Tomasi, J. Chem. Phys. 1982, 65, 239; (c) Cossi, M.; Barone, V.; Cammi, R.; 
Tomasi, J. Chem. Phys. Lett. 1996, 255, 327; (d) Tomasi, J.; Mennucci, B.; Cammi, R. Chem. Rev. 2005, 105, 2999.

S17. Tenderholt, Adam L. QMForge, Version 2.1, http://qmforge.sourceforge.net.

S18. Avogadro: an open-source molecular builder and visualization tool. Version 1.1.1 http://avogadro.openmolecules.net/ 